\title{
Layer-Specific Intracolumnar and Transcolumnar Functional Connectivity of Layer V Pyramidal Cells in Rat Barrel Cortex
}

\author{
Dirk Schubert, ${ }^{1,2}$ Jochen F. Staiger, ${ }^{2}$ Nichole Cho, ${ }^{2}$ Rolf Kötter, ${ }^{2,3}$ Karl Zilles, ${ }^{2,4}$ and Heiko J. Luhmann ${ }^{1}$ \\ ${ }^{1}$ Institute of Neurophysiology, ${ }^{2}$ C. \& O. Vogt-Institute for Brain Research, 3/nstitute of Morphological Endocrinology and \\ Histochemistry, University of Duesseldorf, D-40001 Duesseldorf, Germany, and 4Institute of Medicine, Research Center \\ Juelich, D-52425 Juelich, Germany
}

Layer $\mathrm{V}$ pyramidal cells in rat barrel cortex are considered to play an important role in intracolumnar and transcolumnar signal processing. However, the precise circuitry mediating this processing is still incompletely understood. Here we obtained detailed maps of excitatory and inhibitory synaptic inputs onto the two major layer $V$ pyramidal cell subtypes, intrinsically burst spiking (IB) and regular spiking (RS) cells, using a combination of caged glutamate photolysis, whole-cell patch-clamp recording, and three-dimensional reconstruction of biocytin-labeled cells. To excite presynaptic neurons with laminar specificity, the release of caged glutamate was calibrated and restricted to small areas of $50 \times 50 \mu \mathrm{m}$ in all cortical layers and in at least two neighboring barrel-related columns. IB cells received intracolumnar excitatory input from all layers, with the largest EPSP amplitudes originating from neurons in layers IV and VI. Prominent transcolumnar excitatory inputs were provided by presyn- aptic neurons also located in layers IV, V, and VI of neighboring columns. Inhibitory inputs were rare. In contrast, RS cells received distinct intracolumnar inhibitory inputs, especially from layers II/III and V. Intracolumnar excitatory inputs to RS cells were prominent from layers $\mathrm{II}-\mathrm{V}$, but relatively weak from layer VI. Conspicuous transcolumnar excitatory inputs could be evoked solely in layers IV and V. Our results show that layer V pyramidal cells are synaptically driven by presynaptic neurons located in every layer of the barrel cortex. RS cells seem to be preferentially involved in intracolumnar signal processing, whereas IB cells effectively integrate excitatory inputs across several columns.

Key words: barrel cortex; layer V; pyramidal cell; burst spiking; regular spiking; functional connectivity; excitatory inputs; inhibitory inputs; morphology; electrophysiology; biocytin; caged glutamate; somatosensory; slices
Cortical information processing is mediated by complex interactions between local neuronal circuits within functional columns involving several classes of excitatory and inhibitory neurons. The barrel field in the primary somatosensory cortex of rodents is a particularly useful model for the investigation of cortical columnar organization and signal processing, because the functional columns can be recognized even in unstained living slices (Agmon and Connors, 1991; Kötter et al., 1998). Here neuronal clusters in layer IV (barrels) are related to principal whiskers on the contralateral side of the face in a one-to-one relationship (Woolsey and Van der Loos, 1970; Welker and Woolsey, 1974). Together with supragranular and infragranular neurons, in register with a barrel, they form a functional (barrel-related) column and respond preferentially to stimulation of the whisker, which is topographically related to the barrel within this column (Armstrong-James, 1975; Simons, 1978). However, substantial signal integration occurs not only within but also between barrelrelated columns. Because of the size of their receptive fields, which can comprise a multitude of whiskers (Simons, 1985; Zhu and Connors, 1999), pyramidal cells in supragranular and infra-

Received Jan. 18, 2001; revised March 5, 2001; accepted March 6, 2001.

This study was supported by the Gesellschaft der Freunde und Foerderer der Heinrich-Heine-Universitaet, Duesseldorf, the C. \& O. Vogt-Institut fuer Hirnforschung GmbH, the Gertrud Reemtsma Stiftung, and Deutsche Forschungsgemeinschaft Grant Lu 375/3-2 to H.J.L. We thank U. Opfermann-Emmerich for skilled technical assistance.

Correspondence should be addressed to Dirk Schubert, Institute of Neurophysiology, Heinrich-Heine-University Duesseldorf, POB 101007, D-40001 Duesseldorf, Germany. E-mail: schubd@uni-duesseldorf.de.

Copyright (C) 2001 Society for Neuroscience $\quad 0270-6474 / 01 / 213580-13 \$ 15.00 / 0$ granular layers are considered to play a crucial role in this signal integration (Staiger et al., 2000).

In layer $\mathrm{V}$ of the cerebral cortex, two major classes of pyramidal cells have been described: intrinsically burst spiking (IB) and regular spiking (RS) cells (Connors et al., 1982; Chagnac-Amitai et al., 1990; Larkman and Mason, 1990). The thick, tufted IB cells are capable of discharging high-frequency bursts of action potentials and show extensive horizontal axonal projections within infragranular layers and diverse corticof ugal projections (Kasper et al., 1994). The dendritically rather sparsely arborizing RS cells discharge more regularly and project extensively to supragranular layers (Chagnac-Amitai et al., 1990) and to ipsilateral and contralateral cortical areas (Wise and Jones, 1976). Extensive synaptic coupling between pyramidal cells within layer V (Markram et al., 1997) and between pyramidal cells in layer II/III and layer V (Reyes and Sakmann, 1999) was demonstrated using paired recordings (Thomson et al., 1993; Thomson and Deuchars, 1994). Moreover, layer V pyramidal cells receive inhibitory inputs from different laminar origins, and the spatial organization of these inputs varies with the class of the pyramidal cell (Nicoll et al., 1996). These findings indicate the existence of complex excitatory and inhibitory inputs modulating the functional status of layer $\mathrm{V}$ pyramidal cells. To receive detailed information about the spatial distribution of synaptic inputs, it is necessary to stimulate numerous presynaptic sites covering a sufficiently large cortical area and to construct a synaptic input map for each single cell. Thus we investigated the spatial distribution and strength of excitatory and inhibitory synaptic inputs onto layer $\mathrm{V}$ pyramidal cells using a combination of caged glutamate photolysis and whole-cell patch- 


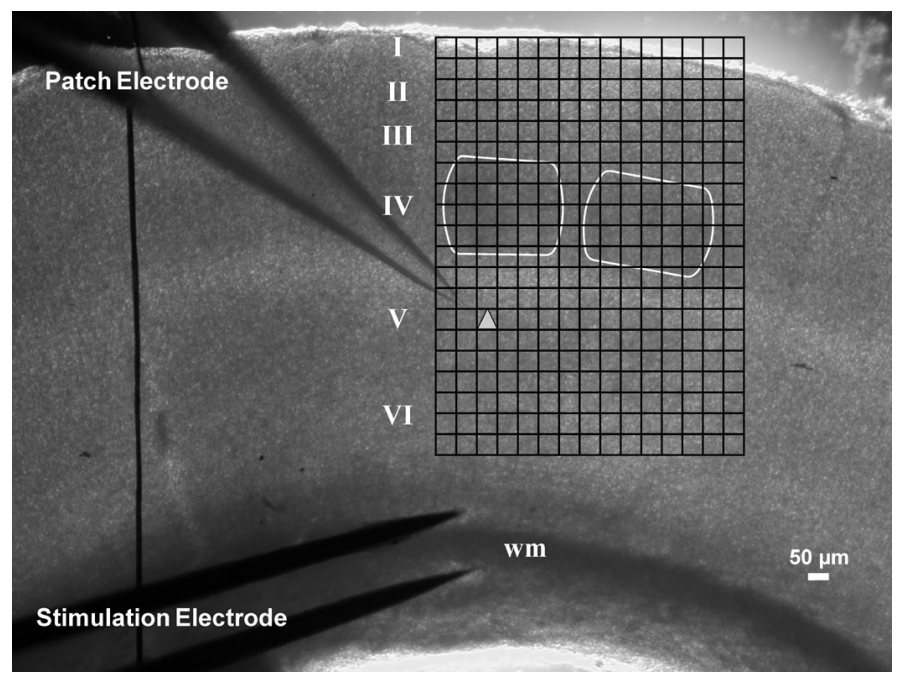

Figure 1. Photomicrograph taken directly after an experiment of a living unstained coronal slice of the somatosensory cortex with positioned electrodes. The tip of the patch electrode points at a pyramidal cell in layer V (position marked by a gray triangle). The bipolar stimulation electrode is placed in the white matter $(\mathrm{wm})$ for electrical stimulation of the afferents. The grid superimposed on the micrograph indicates the relative location and the extent of the area typically used for investigating the functional connectivity of layer V pyramidal cells. Fields (450) $50 \times$ $50 \mu \mathrm{m}$ in size were stimulated in sequence at $10 \mathrm{sec}$ intervals covering all cortical layers and at least two barrel-related columns. The two barrels in layer IV located within the investigated area are outlined by white lines. Roman numerals indicate cortical layers.

clamp recordings. Thereby we obtained detailed maps of layerspecific intracolumnar and transcolumnar functional connectivity of electrophysiologically characterized and morphologically reconstructed RS and IB cells that demonstrate a differential involvement of the two cell types in local cortical circuits.

Part of this study was published previously in abstract form (Schubert et al., 2000).

\section{MATERIALS AND METHODS}

Slice preparation and chemicals. We prepared coronal slices from rat somatosensory cortex containing the barrel cortex (Par1) (Paxinos and Watson, 1986). Male Wistar rats (postnatal days 18-22) were deeply anesthetized with enflurane and decapitated. Blocks of tissue containing the barrel cortex were excised, quickly removed from the skull, and stored in ice-cold artificial CSF (ACSF) oxygenated with carbogen $(95 \%$ $\mathrm{O}_{2} / 5 \% \mathrm{CO}_{2}$ ). Normal ACSF consisted of (in $\mathrm{mM}$ ): $124 \mathrm{NaCl}, 1.25$ $\mathrm{NaH}_{2} \mathrm{PO}_{4}, 26 \mathrm{NaHCO}_{3}, 1.6 \mathrm{CaCl}_{2}, 1.8 \mathrm{MgCl}_{2}, 3 \mathrm{KCl}, 10$ glucose, at $\mathrm{pH}$ 7.4. To block synaptic transmission, modified ACSF containing 0.2 $\mathrm{CaCl}_{2}, 4 \mathrm{MgSO}_{4}$ (low $\mathrm{Ca}^{2+} /$ high $\mathrm{Mg}^{2+} \mathrm{ACSF}$ ) was used. The tissue block was glued to the chilled platform of a Vibratome (Series 1000, TPI, St. Louis, MO) and submerged in ice-cold carbogenated ACSF. Slices of $300 \mu \mathrm{m}$ nominal thickness were cut and incised along the midline to separate the hemispheres. The slices were stored in an incubation chamber containing carbogenated $\mathrm{ACSF}$ at $34^{\circ} \mathrm{C}$ for at least $1 \mathrm{hr}$. The slices were then transferred to the recording chamber and submerged in ACSF at a flow rate of $\sim 1 \mathrm{ml} / \mathrm{min}$ at $32^{\circ} \mathrm{C}$. During the application of caged glutamate, a total amount of $\sim 5 \mathrm{ml}$ ACSF containing the caged compound was continuously oxygenated and recirculated. The caged glutamate (L-glutamic acid, $\gamma$-[ $\alpha$-carboxy-2-nitrobenzyl $]$ ester; Molecular Probes, Eugene, OR) was dissolved in ACSF and added to the circulating ACSF, resulting in a $1 \mathrm{~mm}$ concentration.

Identification of layer V pyramidal neurons. The slices were placed in a fixed stage, submerged chamber under an upright microscope (Axioskop FS, Carl Zeiss, Göttingen, Germany) fitted with a $2.5 \times$ and a $40 \times$ water-immersed objective ( $40 \times / 0.75 \mathrm{~W}$; Olympus, Hamburg, Germany). The barrel field was visualized at low magnification (Fig. 1), and a target region in layer $\mathrm{V}$, which was in vertical register with a barrel, was selected. Individual pyramidal cells were visually identified at $40 \times$ mag- nification using infrared enhanced quarter-field illumination. A bipolar tungsten stimulating electrode was placed in deep layer VI of the same column.

Electrophysiology. Whole-cell patch-clamp recordings from the selected pyramidal cells were performed in current-clamp mode using patch pipettes (4-6 M $\Omega$ ) pulled from borosilicate glass capillaries $(1.5 \mathrm{~mm}$ outer diameter, $1.16 \mathrm{~mm}$ inner diameter; Science Products, Hofheim, Germany) on a Narishige PP-830 puller (Narishige, Tokyo, Japan). The patch pipettes were filled with (in $\mathrm{mM}$ ): $13 \mathrm{KCl}, 117 \mathrm{~K}$-gluconate, 10 K-HEPES, $2 \mathrm{Na}_{2} \mathrm{ATP}, 0.5 \mathrm{NaGTP}, 1 \mathrm{CaCl}_{2}, 2 \mathrm{MgCl}_{2}, 11$ EGTA, and $1 \%$ biocytin. After obtaining a stable seal of $>1 \mathrm{G} \Omega$, the whole-cell configuration was achieved by gentle suction. The cells were electrophysiologically characterized by recording their resting membrane potential and their intrinsic membrane properties under current-clamp conditions by injecting depolarizing and hyperpolarizing current pulses. Orthodromic synaptic responses were elicited with the bipolar stimulating electrode (200 $\mu \mathrm{sec}$ duration at $0.1 \mathrm{~Hz}$ ). To exclude possible influences of caged glutamate on the properties of the recorded cells, electrophysiological characterization and long time recordings were performed in ACSF alone as well as in ACSF containing caged glutamate. Their results were virtually identical.

Scanning of glutamate evoked activity. The setup that we used for the photolysis of caged glutamate has been described previously (Kötter et al., 1998). However, to implement single-cell recordings, some modifications were necessary. We added a circular linear-wedge neutral-density filter into the light path $\left(D_{\mathrm{r}}=0.0-2.0\right)$ (Melles Griot, Irvine, CA) for the exact calibration of the illumination intensity. The light pulses $(\sim 500$ $\mu \mathrm{sec})$ were focused on areas that were $50 \times 50 \mu \mathrm{m}$ large, with the focus plane $\sim 50-80 \mu \mathrm{m}$ deep in the slice, which was equal to the depth of the recorded cell soma. The membrane potential was recorded during every photostimulus. In the beginning of the study, fields at varying distances from a recorded soma were stimulated, always with use of the same stimulation strength. This was done to ensure that the photostimulation provided layer-specific excitation. In ACSF, aside from layer $\mathrm{V}$ pyramidal cells $(n=42)$, other neurons in layers II/III, IV, V and VI also were recorded at the resting membrane potential $\left(V_{\mathrm{rmp}}\right)$ of the cells $(n=19)$. In none of these control experiments could action potentials be elicited by photostimulation at distances $>100 \mu \mathrm{m}$ from the soma. In two of five pyramidal cells in layer II/III, no suprathreshold activation was evoked from any of the tested fields. Every $10 \mathrm{sec}$ the stimulation area was moved in a meandering fashion across a rectangular field for further scanning in steps of $50 \mu \mathrm{m}$ (Fig. 1). While the synaptic connectivity was mapped, the cell was held at a potential $\left(V_{\text {hold }}\right)$ of $-60 \mathrm{mV}$ in current-clamp mode to reveal hyperpolarizing inhibitory inputs. As shown in Figure 1, the scanned cortical areas included at least two barrel-related columns from layers I-VI, and thus up to 450 different fields were stimulated without any intermittent gaps. To determine the spatial distribution of glutamateevoked direct activity in the recorded cell, we blocked synaptic transmission using ACSF containing low $\mathrm{Ca}^{2+} /$ high $\mathrm{Mg}^{2+}$. The intrinsic properties of the recorded cell were controlled before and after termination of each map.

Data acquisition and analysis. The signals were amplified (SEC-05L; npi-electronics, Tamm, Germany), filtered at $3 \mathrm{kHz}$, and digitized using an ITC-16 interface (Instrutech, Great Neck, NY). Data were recorded, stored, and analyzed with PC-based software (TIDA 4.1 for Windows; Heka Electronik, Lambrecht, Germany). After recording, the slices were photographed in the bath chamber to document the topography of barrel-related columns and laminae as well as the respective position of the patch and stimulating electrode. Slices were then fixed in $4 \%$ buffered paraformaldehyde and stored at $4^{\circ} \mathrm{C}$. For visualization of the biocytinfilled neurons, the slices were processed using a previously described protocol (Angulo et al., 1999). Reconstruction and morphological analyses of the biocytin-labeled neurons were made using a Nikon Eclipse 800 (Nikon, Ratingen, Germany) attached to a computer system (Neurolucida; Microbrightfield Europe, Magdeburg, Germany). IB and RS cells were compared in terms of the following morphological properties: soma area, total length of apical and basal dendrites, total number of branches of the apical dendrite, and the maximal diameter of the apical trunk. The data were not corrected for tissue shrinkage. The reconstructed cells were superimposed onto the photomicrograph of the native slice using standard graphics software.

Different maps of glutamate-induced activity obtained in low $\mathrm{Ca}^{2+}$ / high $\mathrm{Mg}^{2+}$ containing ACSF were constructed using (1) flash evoked peak amplitudes and (2) delays between stimulus and onset of activity. For maps in normal ACSF, the following properties of stimulus-induced 
Figure 2. Action potential firing pattern $(A-C)$ and synaptic responses $(D, E)$ of layer $\mathrm{V}$ pyramidal cells. $A$, Response of an intrinsically burst spiking cell (IB cell) to injection of a suprathreshold depolarizing current pulse at resting membrane potential. The initial burst consists of an action potential followed by a DAP with three spikes of decreasing amplitude. The initial burst is followed by a sequence of single APs. $B$, In the doublet spiking cell, the intracellular current pulse elicits an initial action potential followed by a small DAP with one spike and subsequent single APs with no spike-frequency adaptation. $C$, In the regular spiking cell (RS cell), the depolarizing current evokes a train of single APs without any DAP. $D$, Postsynaptic responses of an IB cell to strong orthodromic stimulation $(2 \times$ threshold; arrow) at different membrane potentials. The stimulus evokes a burst and a long lasting EPSP. E, Orthodromic synaptic stimulation of the RS cell elicits a single spike and an EPSP truncated by a fast $\left(^{*}\right)$ and a slow $(* *)$ IPSP.
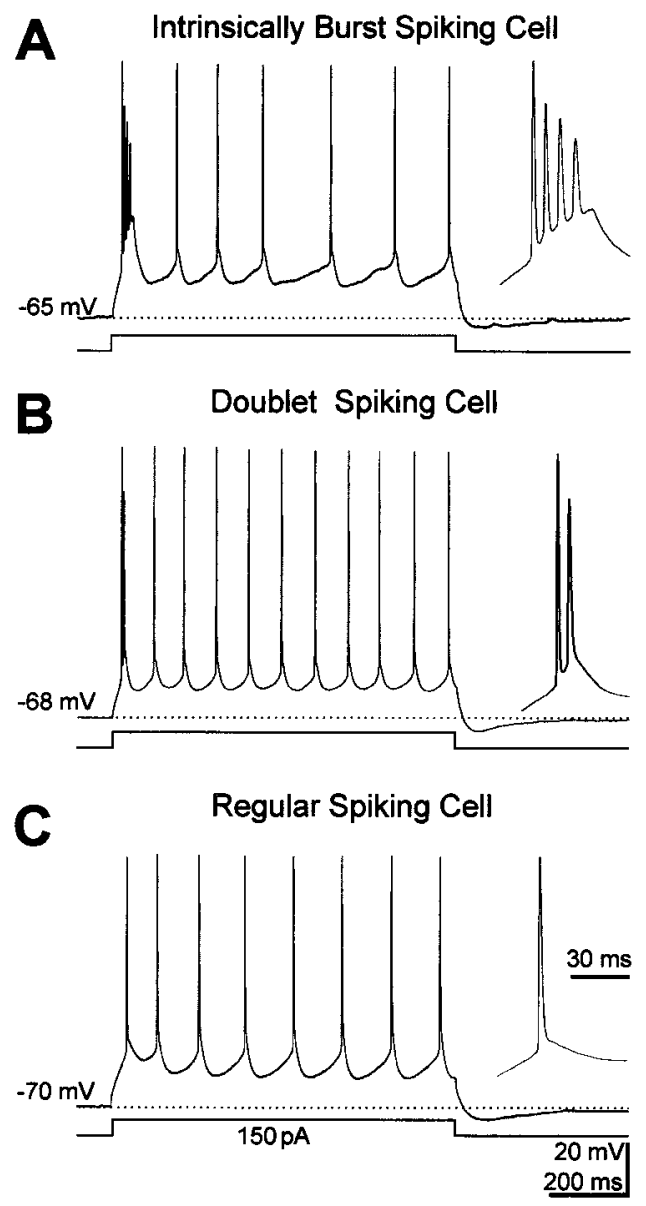
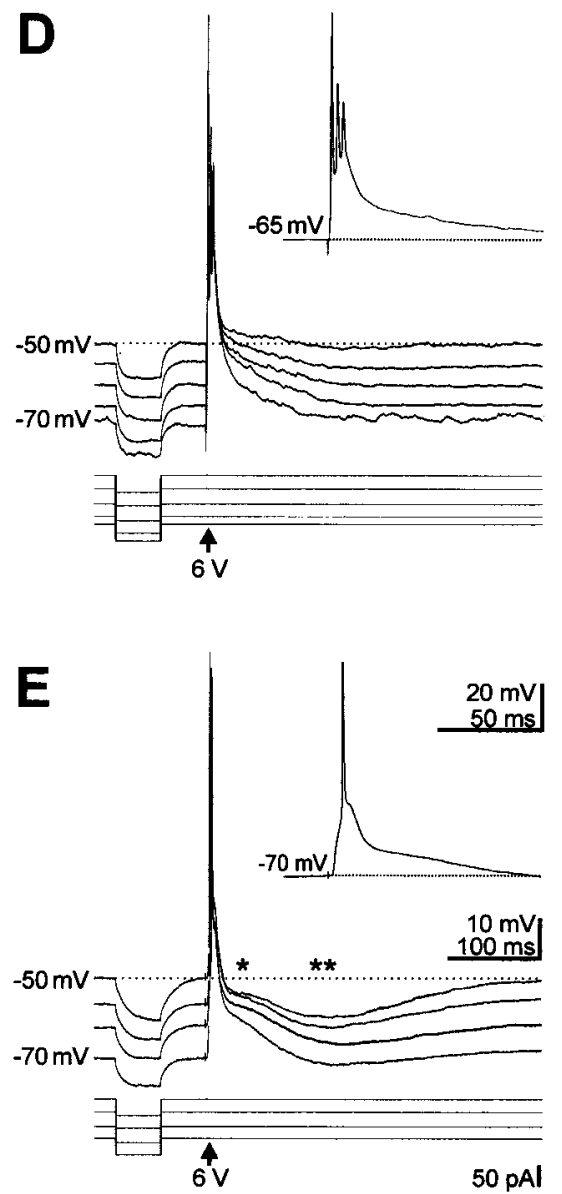

activity were analyzed within a time window of $150 \mathrm{msec}$ after stimulus for each single trace: (1) delay-to-onset of stimulus-evoked activity, (2) occurrence of IPSPs, (3) maximal peak amplitude, and (4) integral of all EPSPs. Only subthreshold responses with amplitudes of $>0.2 \mathrm{mV}$ were included for further analysis. In control experiments using repetitive photostimulation, we additionally analyzed (1) the delay between stimulus and action potential threshold (action potential latency), (2) the peak amplitude of the first EPSP, and (3) 20-80\% rise-time of the first EPSP. Spontaneous activity with amplitudes of $>0.2 \mathrm{mV}$ was very rare and, when present, was excluded from further analysis. Response properties that were analyzed were transformed into pseudocolored values using the software Origin 6.0 (Microcal Software, Northampton, MA), and the resulting maps were superimposed on the respective sites on the micrographs. Statistical analysis was performed using repeated measures ANOVA with post hoc pair-wise comparisons (Bonferroni corrected) and unpaired two-tailed Student's $t$ test (SPSS 9; SPSS Inc., Chicago, IL). Data are presented as mean \pm SD.

\section{RESULTS}

In the present study, we investigated 55 layer $\mathrm{V}$ pyramidal cells in rat barrel cortex. For 27 layer V IB/doublet spiking cells and 28 layer V RS cells, whole-cell patch-clamp recordings were combined with topographic mapping of glutamate-induced activity. Complete maps in ACSF including all cortical layers and at least two barrel-related columns were obtained for seven IB cells and eight RS cells. Partially mapped cells (11 IB cells, 12 RS cells) were used for complementary verification of the results obtained from the completely mapped cells. The remaining cells were used for control experiments (see Materials and Methods). Only cells with a stable resting membrane potential negative to $-60 \mathrm{mV}$ during the whole experiment were included in the analysis.

\section{Electrophysiological and morphological identification of RS and IB cells}

As indicated by previous studies, layer $\mathrm{V}$ pyramidal neurons can be divided into RS and IB cells according to their firing properties, their synaptic input pattern in response to orthodromic stimulation, and their specific morphology (Connors et al., 1982; Chagnac-Amitai et al., 1990; Larkman and Mason, 1990; Amitai, 1994; Williams and Stuart, 1999; Hefti and Smith, 2000). In accordance with these studies, we found that IB cells responded to injection of a just suprathreshold depolarizing current pulse with an initial high-frequency burst consisting of two to three action potentials with decreasing amplitudes mounted on a depolarizing after potential (DAP) (Fig. $2 A$ ). This initial burst with a first interspike interval (ISI) of $175 \pm 22 \mathrm{~Hz}(n=17)$ was followed either by rhythmic action potential (AP)-firing or by single APs showing longer ISIs. Injection of current pulses with increasing amplitudes did not alter the first ISI but increased the number of action potentials in the initial burst to three to six spikes. In 10 cells, just suprathreshold as well as increased current injections reproducibly induced doublets of APs at a mean first ISI of $152 \pm 27 \mathrm{~Hz}$ (Fig. $2 B$ ). Except for the different response pattern to depolarizing current injection, these doublet spiking cells were indistinguishable from IB cells and showed the same response to orthodromic stimulation and the same morphology. Thus, doublet spiking cells were added to the group of IB cells in accordance with the description by Schwindt et al. (1997). RS cells, however, responded to suprathreshold current injection with a series of single APs (Fig. $2 C$ ). In 11 of 28 RS cells, the 


\begin{tabular}{lcc}
\hline Table 1. Morphological properties of layer V IB and RS cells \\
& IB cells $(n=7)$ & RS cells $(n=5)$ \\
\hline Soma area $\left(\mu \mathrm{m}^{2}\right)$ & $377.9 \pm 122.7$ & $248.7 \pm 76.4^{*}$ \\
Total length of basal dendrites $(\mu \mathrm{m})$ & $3199 \pm 1210.5$ & $2531.8 \pm 811.1$ \\
Total length of apical dendrite $(\mu \mathrm{m})$ & $6231.7 \pm 3320.6$ & $2153.3 \pm 684.8^{* *}$ \\
Number of branches of apical dendrite & $49.1 \pm 27.6$ & $23.4 \pm 9.6^{*}$ \\
Maximal apical trunk diameter $(\mu \mathrm{m})$ & $6.3 \pm 1.7$ & $4.1 \pm 1.4^{*}$
\end{tabular}

Data are mean $\pm \mathrm{SD} ;{ }^{*} p<0.05,{ }^{* *} p<0.01$.

firing rate became more or less constant after an initial frequency adaptation [comparable to $\mathrm{RS}_{1}$-type in Hefti and Smith (2000)]. In the remaining cells, the firing rate adaptation continued for the duration of the depolarizing current pulse. In 14 of $28 \mathrm{RS}$ cells, APs were followed by a small DAP (comparable to $\mathrm{RS}_{2}$-type). However, rhythmic AP firing or high-frequency bursts/doublets of APs were never observed in RS cells. The average resting membrane potential $\left(V_{\mathrm{rmp}}\right)$ and the membrane resistance $\left(R_{\mathrm{m}}\right)$ were not significantly different between IB cells $\left(V_{\mathrm{rmp}}=-62.6 \pm 3.2\right.$ $\left.\mathrm{mV} ; R_{\mathrm{m}}=133 \pm 64 \mathrm{M} \Omega ; n=27\right)$ and $\mathrm{RS}$ cells $\left(V_{\mathrm{rmp}}=-63.7 \pm\right.$ $\left.3.7 \mathrm{mV} ; R_{\mathrm{m}}=202 \pm 124 \mathrm{M} \Omega ; n=28\right)$.

We also used orthodromic synaptic stimulation for a functional characterization of the two cell types. As demonstrated in Figure $2 D$, orthodromic stimulation evoked an EPSP, eliciting a burst of action potentials in IB cells with no visible IPSP. In contrast, in 19 of 28 RS cells, the initial EPSP was followed by a prominent fast and slow IPSP (Fig. 2E). The remaining nine RS cells showed no detectable IPSPs.

All cells were labeled with biocytin for subsequent morphological identification. All completely filled IB and RS cells showed an apical dendrite reaching layer I $(n=25)$. A quantitative evaluation of cell type-specific morphological properties of reconstructed IB and RS cells is given in Table 1. In agreement with the studies mentioned before, large triangular somata and thick apical dendrites were typical features of IB cells (Fig. $3 A$ ). The apical dendrite usually possessed numerous oblique collateral branches. The main trunk started to bifurcate in layers IV or II/III, giving rise to a rich terminal tuft. The basal dendrites were also extensively ramified. In contrast, RS cells possessed a smaller ovoid soma with a thinner apical trunk and a less ramified apical dendrite (Fig. 3B).

\section{Direct effects of uncaged glutamate}

To investigate the direct effects of uncaged glutamate on functional properties of the recorded cell, we performed experiments in ACSF containing low $\mathrm{Ca}^{2+} /$ high $\mathrm{Mg}^{2+}$ to block synaptic transmission. After $30 \mathrm{~min}$ of perfusion with low $\mathrm{Ca}^{2+} /$ high $\mathrm{Mg}^{2+} \mathrm{ACSF}$, even strong electrical stimuli were not capable of evoking postsynaptic responses in the recorded neuron $(n=4 \mathrm{IB}$ and 5 RS cells). The photolysis of caged glutamate within a field of tissue containing dendritic extensions of the recorded cell led to a transient depolarization (Fig. 4A,B). For both cell types, 20 repetitive flashes at $10 \mathrm{sec}$ intervals on a selected proximal dendritic field revealed a stable pattern of evoked depolarizations. Perisomatic stimulation induced strong depolarizations of 15-20 $\mathrm{mV}$ that reliably elicited a single action potential, doublet, or burst in accordance with electrical characterization (Fig. 4C,D). However, depending on the size of the depolarization amplitude, short trains of action potentials after the initial response also could be elicited (Dantzker and Callaway, 2000). The delay-toonset times within distances of $\leq 100 \mu \mathrm{m}$ from the soma were $<1$
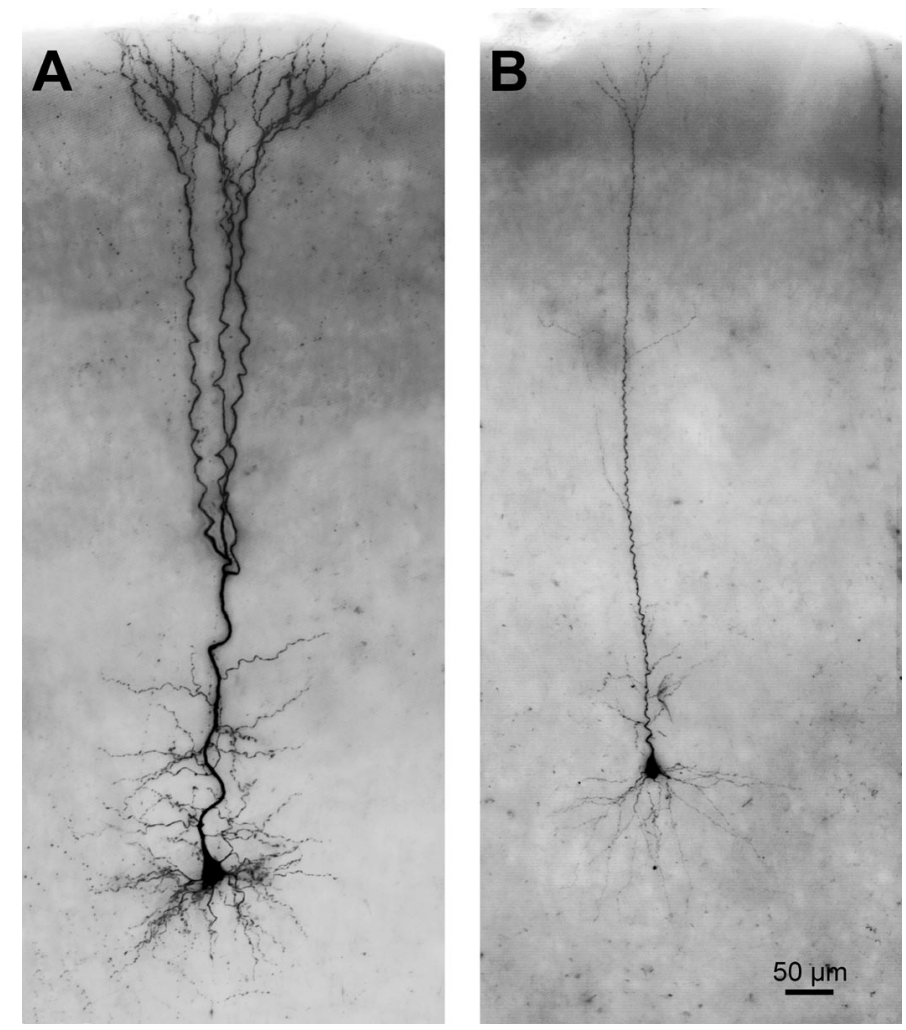

Figure 3. Photoreconstructions of a biocytin-stained intrinsically burst spiking cell $(A)$ and a regular spiking cell $(B)$ in a $300-\mu \mathrm{m}$-thick coronal section of the barrel cortex. $A$, The IB cell shows a large soma and a thick apical dendrite, which gives off oblique collateral branches in layer $\mathrm{V}$ and bifurcates in layer IV, giving rise to a rich terminal tuft. The basal dendrites are also extensively ramified. $B$, The RS cell shows a smaller soma and a thinner apical dendrite. The apical dendritic tree as well as the basal dendrites are ramified less extensively.

$\mathrm{msec}$, and the estimated rise-times were $>5 \mathrm{msec}$. At distances of $>500 \mu \mathrm{m}$ from the soma, the $20-80 \%$ rise-times could increase up to $30 \mathrm{msec}$. Neither the delay-to-onset of activation (Fig. 5A) nor the $20-80 \%$ rise-times (Fig. $5 B$ ) changed significantly during repetitive flash activation. In contrast, the depolarization amplitudes (Fig. 5C) and action potential latencies (Fig. 5D) were more variable.

To determine the spatial distribution of the direct glutamateinduced activity under low $\mathrm{Ca}^{2+} /$ high $\mathrm{Mg}^{2+}$ conditions, we stimulated 250 fields and converted the depolarization amplitudes or the delay-to-onset of activation into color-coded maps (Fig. 6) ( $n=4 \mathrm{IB}$ and $4 \mathrm{RS}$ cells). In the matched figure of the native slice and the reconstructed cell, each colored square indicates the location of a stimulated field of tissue where a depolarizing response was evoked. Figure 6 illustrates the spatial distribution of the glutamate-induced activity for an IB cell. Membrane depolarizations were observed only in fields containing dendritic extensions of the recorded cell. Highest response amplitudes were induced at perisomatic locations and along the proximal dendrites; lowest response amplitudes were induced at peripheral locations of the basal dendrites and at distal parts of the apical dendrite. Action potentials were evoked only by flashing fields very close to the soma. The delay-to-onset of activation (Fig. 6B) and the rise-time (20-80\%; data not shown) directly correlated with the distance of the flashed field to the recording site. The stimulation of fields at or near the soma caused an almost imme- 
Figure 4. Repetitive stimulation of proximal apical dendritic $(A, B)$ and perisomatic $(C, D)$ fields of an IB $(A, C)$ and an RS cell $(B, D)$ via localized release of caged glutamate. The bathing medium contained 0.2 $\mathrm{mM} \mathrm{Ca}^{2+}$ and $4 \mathrm{mM} \mathrm{Mg}^{2+}$ to block synaptic transmission. Inset, Schematic diagram of a pyramidal cell and relative positions of the stimulated areas. $A, B$, Photolysis of caged glutamate in $50 \times 50 \mu \mathrm{m}$ large fields positioned $\sim 150 \mu \mathrm{m}$ away from the soma of the recorded cells and $(C, D)$ on the apical dendrite close to the soma. Repetitive stimulation at $10 \mathrm{sec}$ intervals reliably induces a membrane depolarization, which only during perisomatic stimulation triggers a burst $(C)$ or a single action potential $(D)$. Twenty subsequent traces are superimposed to illustrate the stability of the responses to caged glutamate photolysis. The recordings were performed at resting membrane potential of $-62 \mathrm{mV}$ in the IB cell and $-68 \mathrm{mV}$ in the RS cell.
Intrinsically Burst Spiking Cell

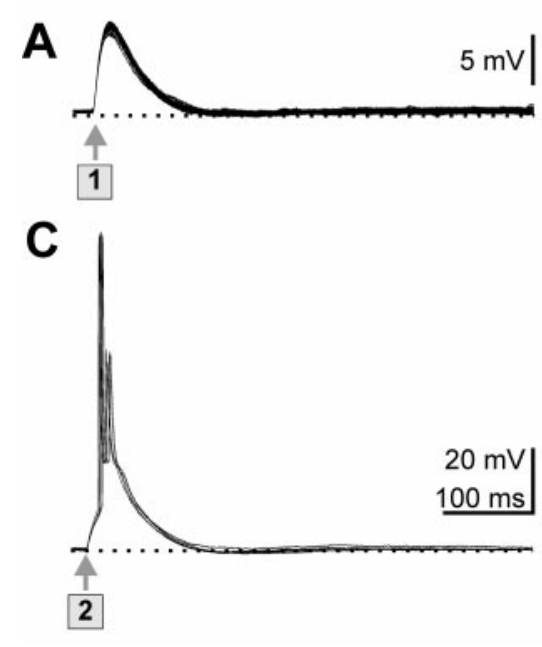

Regular Spiking Cell
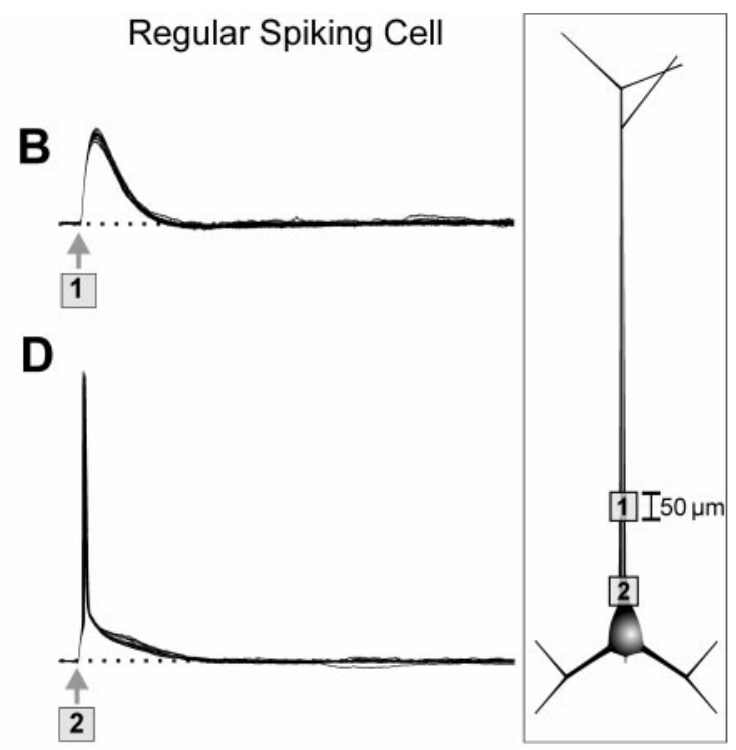

Figure 5. Properties of repetitively evoked activity in bathing solution containing low $\mathrm{Ca}^{2+} /$ high $\mathrm{Mg}^{2+}$. In an area of $50 \times 50 \mu \mathrm{m}$ located on the apical dendrite $\sim 150 \mu \mathrm{m}$ away from the soma, caged glutamate was photolyzed 20 times at 10 $\mathrm{sec}$ intervals at resting membrane potential. Data are normalized to the first response and are presented as mean $\pm \mathrm{SD}$ $(A-C: n=3$ RS cells and 3 IB cells; $D: n=$ 2 RS cells and 2 IB cells). A, Delay-toonset of activation times. $B$, Rise-times (20-80\%) of the responses. $C$, Amplitudes of the elicited depolarizations. $D$, Delay between stimulation and action potential threshold (action potential latency) varied between 80 and $120 \%$ of the initial control value.
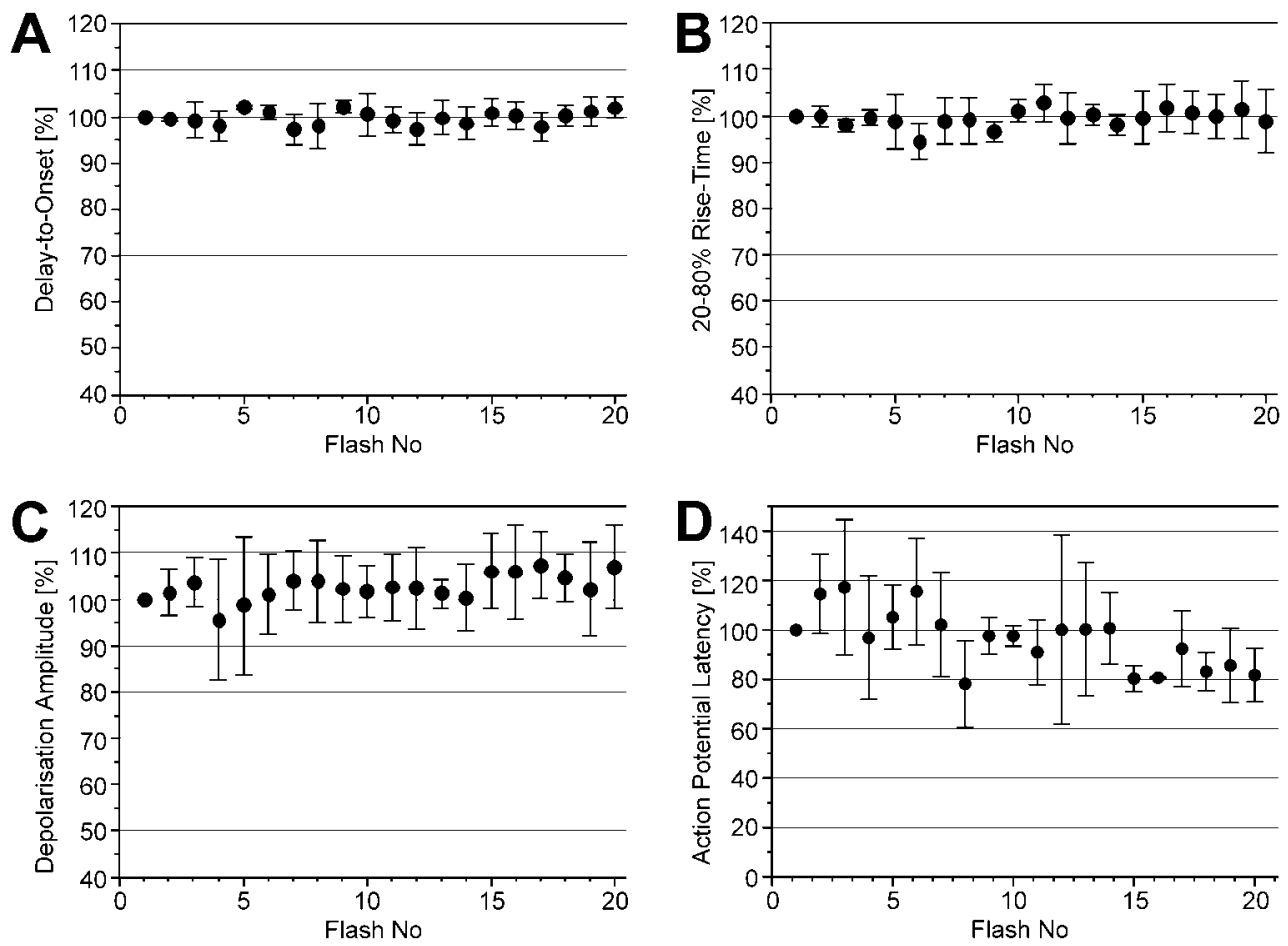

diate depolarization (Fig. 6D3). Longer delay-to-onset times were observed by flashing the apical tuft near the pial surface (Fig. 6D1). A linear regression of the data resulted in the calculation of an average electrotonic propagation velocity of 0.26 $\mathrm{m} / \mathrm{sec}$ along the dendrites (Fig. 6E).

\section{Characterization of synaptically evoked inputs onto layer V pyramidal cells}

In experiments performed in normal ACSF, the uncaged glutamate was able to induce (1) activity resulting from direct stimulation of dendritic extensions of the recorded cell and (2) EPSPs and IPSPs after activation of presynaptic excitatory and inhibitory neurons, respectively. Repetitive stimulation of selected sites was used to characterize the properties of synaptically evoked activity ( $n=4 \mathrm{RS}$ and 4 IB cells). As demonstrated in Figure 7, the recorded IB cell received distinct excitatory and inhibitory synaptic inputs from presynaptically activated neurons. Repetitive stimulation of some fields reliably elicited IPSPs with stable rise-time and delay-to-onset time (Fig. $7 A$ ). However, the amplitude of the IPSPs varied from trial to trial. In other fields, unlike the IPSPs, EPSPs were initiated during repetitive stimulation, with a failure rate of $5-40 \%$ (as at site 2), but with relatively stable amplitudes and rise-times (Fig. $7 B$ ). The delay-to-onset times of the EPSPs varied between 5 and $50 \mathrm{msec}$. Furthermore, the flash often evoked two or multiple EPSPs. As under low $\mathrm{Ca}^{2+} /$ high $\mathrm{Mg}^{2+}$ conditions, perisomatic stimulation reliably elicited an action potential (Fig. $7 C$ ).

Figure $8 A$ shows recordings of two populations of EPSPs after repetitive stimulation at the same site. The two populations 

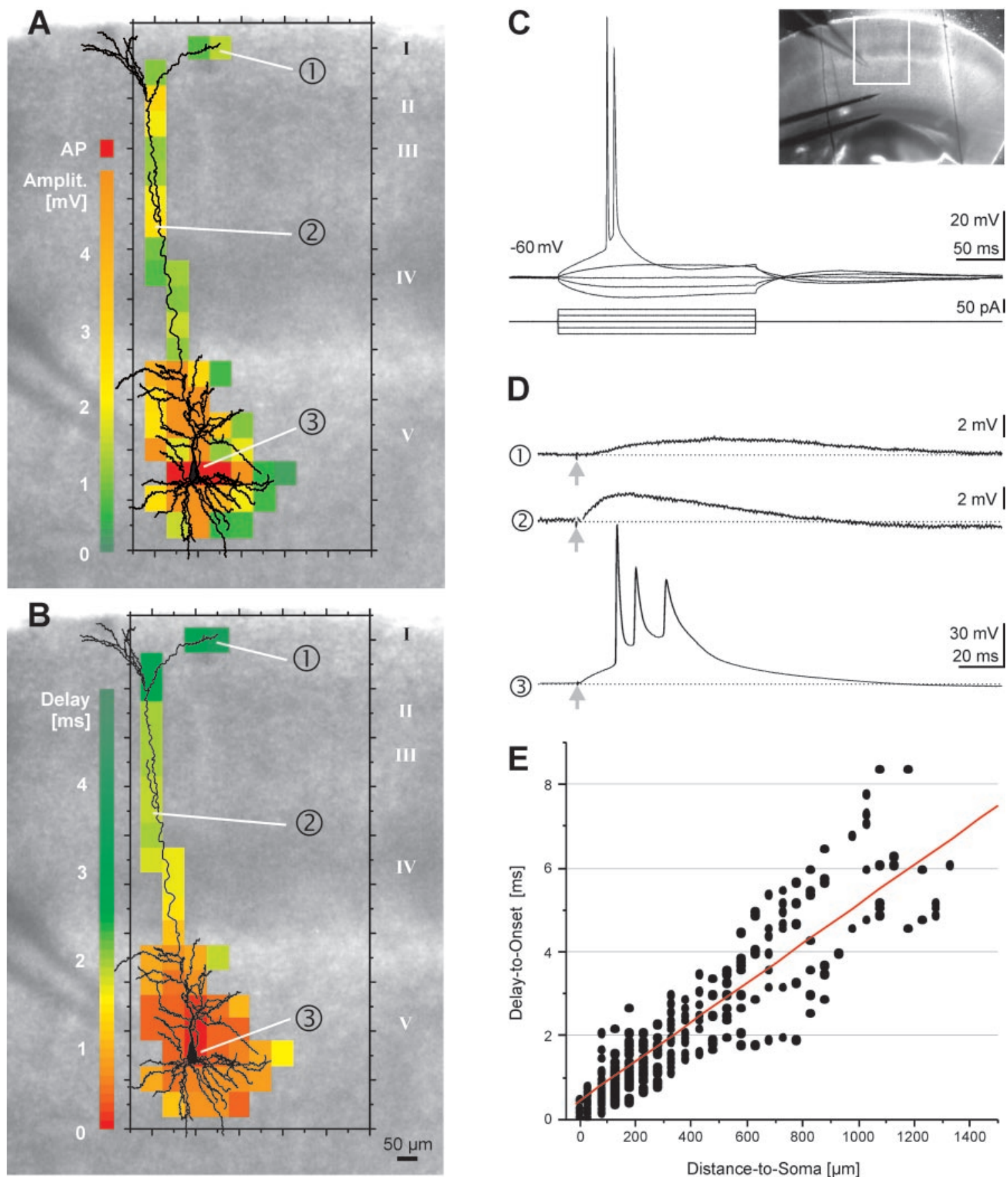

D
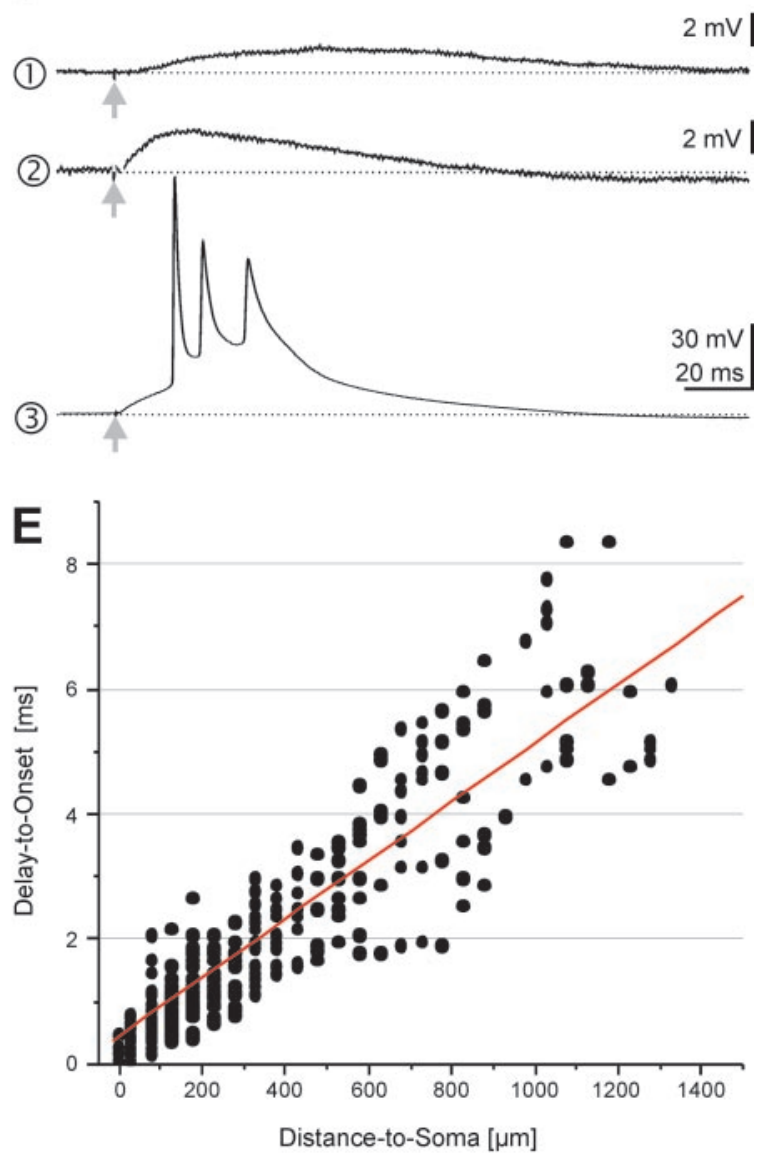

Figure 6. Topographic maps of depolarization amplitude and delay-to-onset of activation times of an $\mathrm{IB}_{\text {cell }}$ in low $\mathrm{Ca}^{2+} / \mathrm{high}^{\mathrm{Mg}}{ }^{2+}$-containing solution. The photomicrograph of the native slice was superimposed on the respective Neurolucida reconstruction of the somatodendritic domains of the IB cell and the map illustrating the amplitudes of induced activity $(A)$ or the delay-to-onset of activation $(B)$. The size of the investigated area is outlined in black. Stimulated fields without any correlated activity are transparent. The colors indicate the depolarization amplitudes, action potentials, or delay-to-onset times (see color scale). The positions of the stimulated fields corresponding to the traces in $D$ are marked $1-3$. $A$, In low Ca ${ }^{2+} / h_{\text {high }} \mathrm{Mg}^{2+}$ ACSF, activity can be evoked only by stimulation of fields containing dendritic extensions of the IB cell. Photolysis induces action potentials in perisomatic fields only. $B$, The delay-to-onset times correlate with the distance of the stimulation site to the soma. Perisomatic stimulation leads almost instantly to an activity $(<0.2 \mathrm{msec})$, whereas activity evoked by stimulation near the pial surface reaches the soma after $>5 \mathrm{msec} C$, Current-voltage relationship identifies the recorded cell as an IB cell. Inset, Photo of the native slice marking the sector presented in $A$ and $B$ (outlined in white). $D$, Responses to photolysis of caged glutamate at positions indicated in $A$ and $B$. With increasing distance from the soma, depolarization amplitudes decrease, whereas the delay-to-onset times increase. Fast suprathreshold depolarization inducing a burst of APs is elicited at stimulation site 3 at the soma. E, Correlation between delay-to-onset times and distance of the stimulation site to the soma for three RS cells and three IB cells. Data were used to calculate an electrotonic propagation velocity of $0.26 \mathrm{~m} / \mathrm{sec}$ (red line, $r=0.967$ ). 
Figure 7. Repetitive postsynaptic responses recorded in normal ACSF in an RS cell $\left(V_{\mathrm{rmp}}=-64 \mathrm{mV}\right)$. Fields 1 and 2 containing no dendritic extensions of the recorded cell were stimulated 20 times at $10 \mathrm{sec}$ intervals. A perisomatic field was stimulated 10 times (field 3). The left column shows a representative single response of the superimposed traces recorded from the RS cell. $A$, Stimulation of field 1 induces a reliable inhibitory input onto the RS cell without any failures. $B$, Stimulation of field 2 induces excitatory inputs onto the RS cell. $C$, The perisomatic stimulation (field 3 ) reliably induces a suprathreshold depolarization. The AP latencies vary between 15 and $25 \mathrm{msec}$.

Figure 8. Properties of excitatory inputs onto layer $\mathrm{V}$ pyramidal cells. Excitatory inputs onto an IB cell $\left(V_{\mathrm{rmp}}=-72 \mathrm{mV}\right)$ induced by repetitive stimulation $(15 \times, 10$ sec intervals) of a field located in layer VI $\sim 250 \mu \mathrm{m}$ from the soma. The stimulation induced two distinct EPSPs with an average amplitude of $2.9 \pm 0.2 \mathrm{mV}$ (EPSP1) and $1.3 \pm 0.2 \mathrm{mV}$ (EPSP2). Superimposed traces $(A 1)$ and selected single traces $(A 2$, $A 3)$ demonstrate the large variability in the delay-to-onset times of EPSP1 and EPSP2. $B$, Variability of the delay-to-onset times. Failure rate is $17 \%$ for EPSP1 and $33 \%$ for EPSP2. Plot of the relationship between EPSP amplitude and integral $(C)$ and plot of the relationship between EPSP amplitude and rise-time $(D)$ demonstrate that both populations of EPSPs can be clearly differentiated.
A

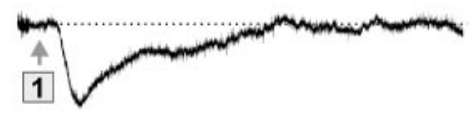

B
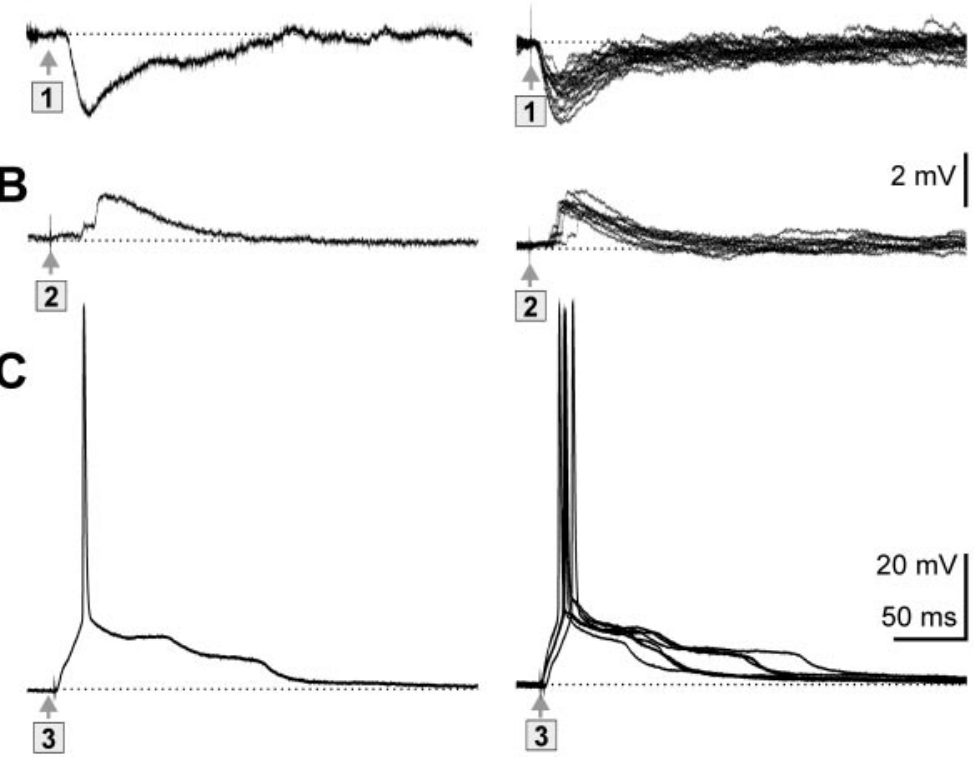
1 .
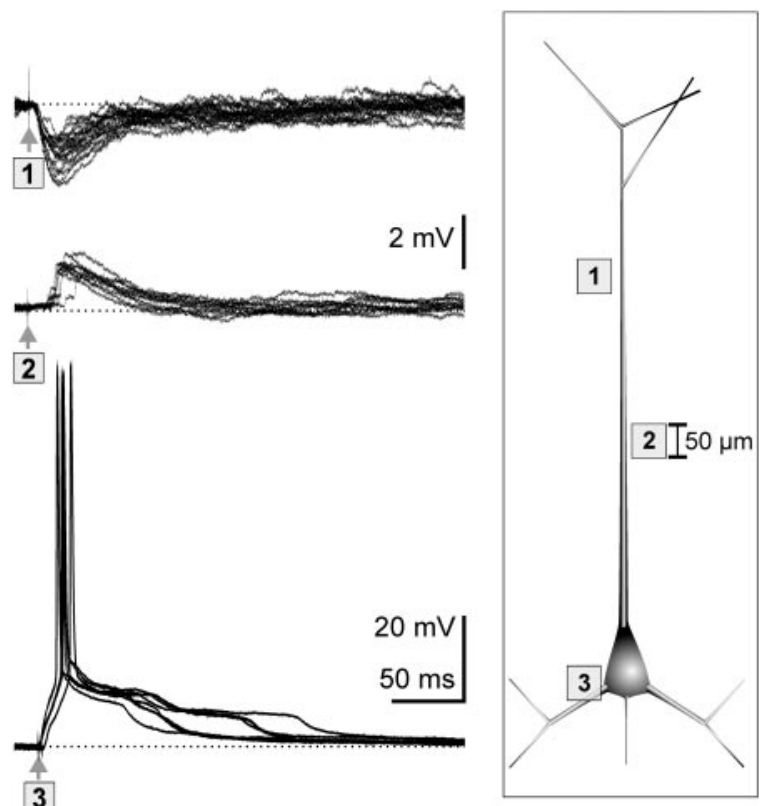

A

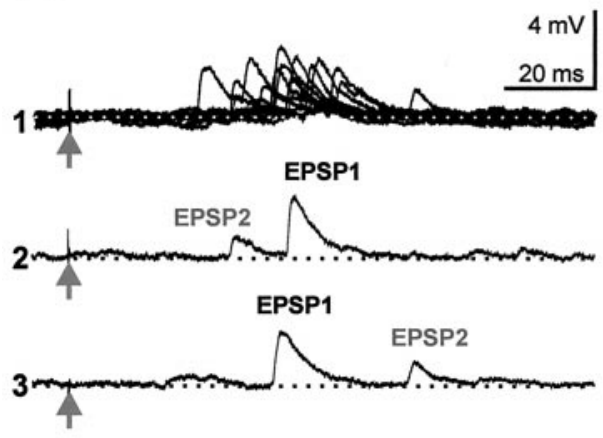

B

C

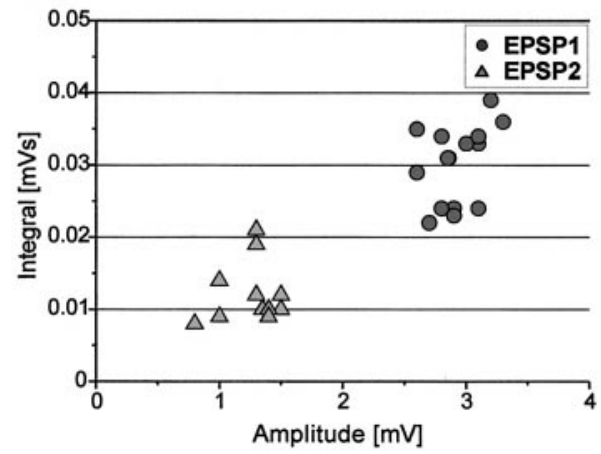

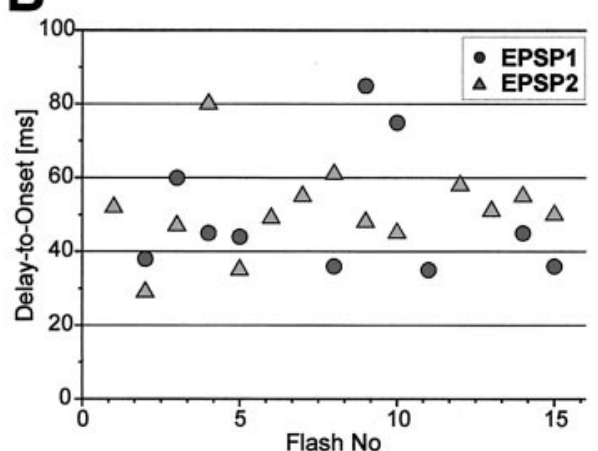

D

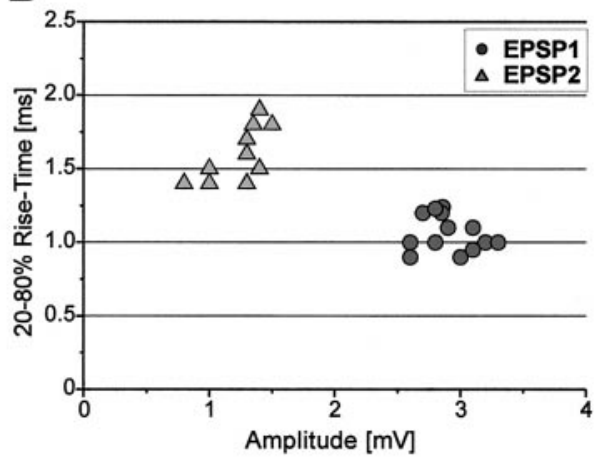

varied not only in their delay to onset but also in their order of appearance (Fig. 8A,B). However, the two populations differed significantly in their mean amplitudes (EPSP1: $2.9 \pm 0.2 \mathrm{mV}$; EPSP2: $1.3 \pm 0.2 \mathrm{mV} ; n=15 ; p<0.001, t$ test), integrals (EPSP1: $0.03 \pm 0.005 \mathrm{mVs}$; EPSP2: $0.012 \pm 0.004 \mathrm{mVs} ; p<0.001)$, and rise-times (EPSP1: $1.1 \pm 0.1 \mathrm{msec}$; EPSP2: $1.6 \pm 0.2 \mathrm{msec} ; p<$ $0.001)$. Therefore, these parameters could be used to distinguish between the EPSPs (Fig. 8C,D). Consequently, the delay-to-onset times could not be used as an indicator for the site of the synaptic input onto the recorded cell.

\section{Intracortical inputs onto layer V pyramidal cells}

For the topographic mapping of the functional connectivity we stimulated 450 different fields of $50 \times 50 \mu \mathrm{m}$ in size comprising an area of all six cortical layers and two or more neighboring barrel-related columns. Stimulation of fields containing dendritic extensions of the recorded cells often resulted in a mixture of direct nonsynaptic activation and synaptic events. Therefore it was necessary to separate the direct nonsynaptic responses from the synaptically evoked activity to obtain "pure" synaptic input 
maps. Figure 9 shows the spatial distribution of evoked responses recorded in low $\mathrm{Ca}^{2+} /$ high $\mathrm{Mg}^{2+}$ ACSF (Fig. 9A) as well as in normal ACSF (Fig. 9B) for an IB cell. Direct nonsynaptic responses recorded in low $\mathrm{Ca}^{2+} /$ high $\mathrm{Mg}^{2+}$ ACSF reached the soma within $8 \mathrm{msec}$ (Fig. 9C, top panel). In normal ACSF, we always observed a comparable amount of evoked events within the first $8 \mathrm{msec}$ (Fig. 9C, bottom panel). The remaining events were recorded with delay-to-onset times of $>11 \mathrm{msec}$. In accordance with the morphology of the cell, all responses with delayto-onsets $\leq 8 \mathrm{msec}$ could be related to direct nonsynaptic activation of the dendritic extensions (Fig. 9B,D). Therefore, we could construct maps specifically showing synaptic inputs to the recorded cells (Fig. 9B). Aside from various subthreshold events, several sites were found to induce action potentials $>100 \mu \mathrm{m}$ away from the soma. This is explained by the fact that during mapping the recorded cells were depolarized by up to $10 \mathrm{mV}$ to reach $V_{\text {hold }}=-60 \mathrm{mV}$. Control stimulations of the respective fields after mapping at $V_{\text {rmp }}$ never evoked APs (data not shown).

Typical spatial distribution and strength of synaptic inputs onto an IB and an RS cell are illustrated in Figure 10. The maps clearly indicate that the IB as well as the RS cell received excitatory inputs from neurons located in layers II-VI within the same column and, to a lesser degree, also from the adjacent barrelrelated column. The spatial distribution of fields providing excitatory inputs was generally continuous in infragranular layers and more patchy in the granular and supragranular layers. Especially in layers II/III, EPSPs could be elicited predominantly in fields near the apical dendrite of the recorded cells. In contrast to the EPSPs, inhibitory inputs were spatially more limited to fields in layers II/III and V of the same column.

Stimulation of presynaptic fields often elicited multiple EPSPs. To estimate the strength of excitatory input we determined the integral of all synaptically evoked excitatory events within a time window of $150 \mathrm{msec}$ after stimulus. In several cases, photostimulation elicited synaptically evoked events as well as a direct response. Whenever possible, we separately calculated the integral of the synaptically evoked events only. In the remaining cases the traces were excluded from the integral analysis. The integrals of EPSPs ranged in $69 \%$ from 0.01 to $0.05 \mathrm{mVs}$. For both cell types, integrals obtained from fields in layers II/III normally did not exceed these values. However, "hot spots" of excitatory input could be found in layers IV, V, and VI, mainly located intracolumnarly. In these fields the integrals comprised a multitude of EPSPs and could reach 0.1-1 mVs. Especially in layer IV, hot spots could be found in discrete patches adjoining fields delivering no or very weak input. To analyze layer- and column-specific distribution of excitatory input, the mean integrals values within each layer and column were calculated. In general, excitatory input arising from intracolumnarly located fields was significantly stronger than from transcolumnarly located fields $(p=0.001$, ANOVA). Integrals of EPSPs arising from layer II/III were significantly weaker than from layers IV $(p=0.03)$ and $\mathrm{V}(p=$ 0.02 ). However, within the layers the statistical analysis of excitatory integrals showed a high variability because of the large range of integral values. Thus, a significant cell type-dependent difference was not detectable.

Significant cell type-specific differences were found in the distribution of excitatory and inhibitory synaptic inputs originating from the same and neighboring columns $(p=0.03)$. The quantitative analysis of the spatial distribution of synaptic input demonstrates that both cell types received widespread excitatory inputs from all cortical layers (Fig. 11A). The input was most prominent from within their respective column $(p<0.001)$. The prevalent source of excitatory inputs onto IB cells was layer VI. On average, $88 \pm 7 \%$ of the intracolumnar and $54 \pm 15 \%$ of the transcolumnar layer VI fields elicited an EPSP in IB cells. For the remaining layers, average intracolumnar inputs varied between 33 and $64 \%$, and transcolumnar inputs varied between 19 and $43 \%$. RS cells received most of their excitatory inputs from fields in layer V; $60 \pm 17 \%$ of the intracolumnarly and $28 \pm 17 \%$ of the transcolumnarly located fields delivered excitatory input during stimulation. For the remaining layers the average intracolumnar inputs varied between 25 and 53\%; transcolumnar inputs varied between 8 and $21 \%$. Intracolumnarly, a significant difference between the amount of excitatory inputs onto IB and RS cells was observed in layer V I only ( $p<0.001, t$ test). IB neurons received significantly stronger transcolumnar excitatory inputs from layer VI $(p=0.001, t$ test $)$, layer IV $(p=0.05)$, and layer II/III ( $p=$ $0.02)$ than RS cells.

Inhibitory inputs as well originated from layer II-VI (Fig. $11 B$ ). Intracolumnar inhibitory inputs onto IB cells could be demonstrated from layers II/III and IV as well as V and amounted to $<2 \%$. Weak transcolumnar inhibitory inputs originated only from layer V. On the other hand, RS cells received significantly more intracolumnar inhibitory inputs from fields in layers II $/$ III ( $7.5 \% ; p<0.001, t$ test $)$ and V $(8.3 \% ; p=0.003)$. In layer II/III, inhibitory inputs were often aligned to the apical dendrite of the RS cells. Occasionally RS cells also received distinct inhibitory inputs from fields in layers IV and VI, but because of their high variability these values were not significantly different compared with the IB cells. The differences in the strength of the inhibitory and excitatory synaptic inputs between RS and IB cells became even more apparent after the ratio was calculated between fields providing excitatory and fields providing inhibitory inputs for both cell types (Fig. 11C). IB cells revealed on average a 10 -fold higher ratio of excitatory to inhibitory inputs than RS cells (IB: $84 \pm 55, n=7$; RS: $8 \pm 2, n=8$; $p<0.001$, ANOVA).

\section{DISCUSSION}

In the present study we combined whole-cell recordings with biocytin-containing electrodes and local photolysis of caged glutamate to study the intracortical synaptic inputs onto layer $\mathrm{V}$ pyramidal cells in rat barrel cortex in vitro. We were able to show that the excitatory projection neurons of layer $\mathrm{V}$, i.e., intrinsically burst spiking and regular spiking pyramidal cells, each possess a number of unique connectional properties. Remarkable are the previously undescribed prominent excitatory inputs from layers IV and VI that were stronger for IB than for RS cells, intracolumnarly and transcolumnarly. Furthermore, we could directly show the laminar origins and distribution of inhibitory inputs, which were much more prominent in RS than in IB cells.

\section{Technical considerations}

We have shown previously with extracellular recording techniques that long-term stable responses can be obtained by local release of (gamma-CNB)-caged L-glutamic acid in rat cortical slices (Kötter et al., 1998). Here, we focused on layer V pyramidal neurons and performed a number of important control experiments to evaluate our setup for analyses at the single-cell level. We reduced the intensity of the UV flash and the size of the activated area to reliably elicit an action potential only during stimulation of perisomatic fields restricted to $50-100 \mu \mathrm{m}$ from the 
A
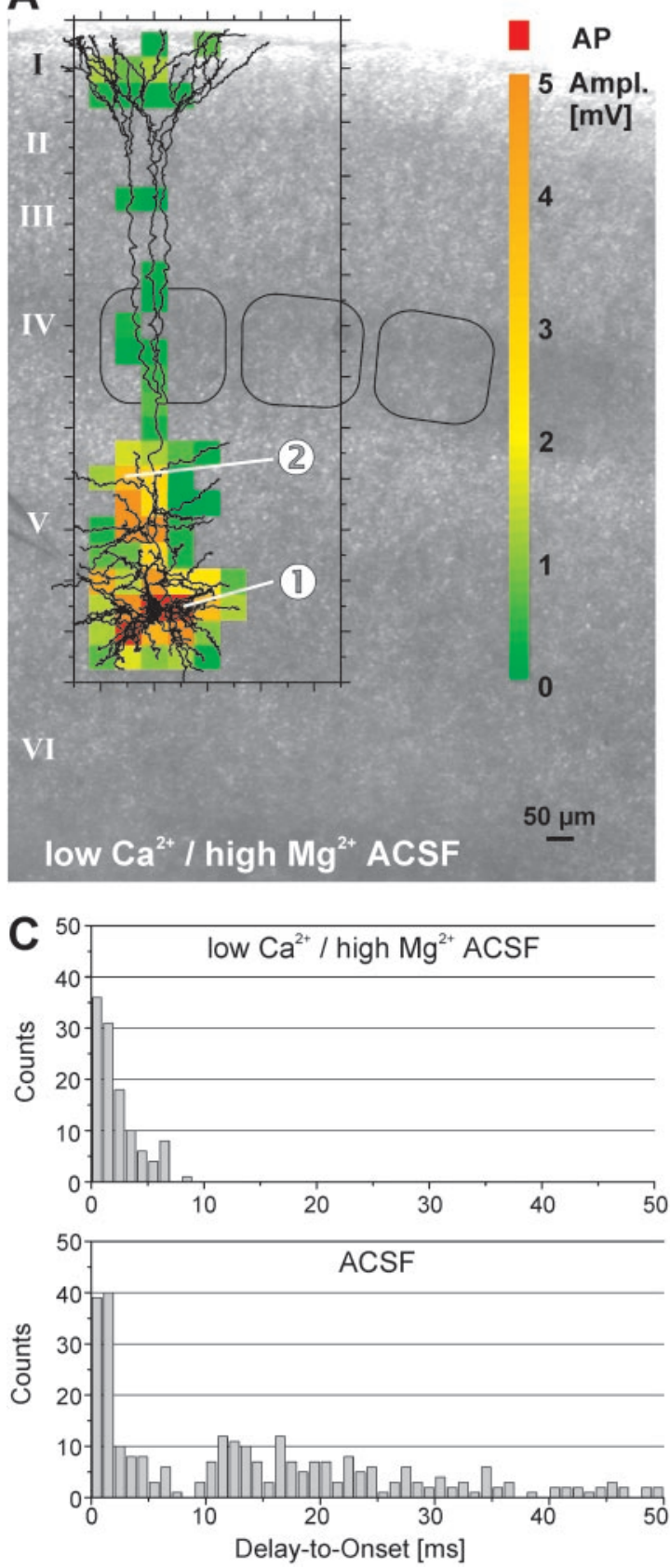

B

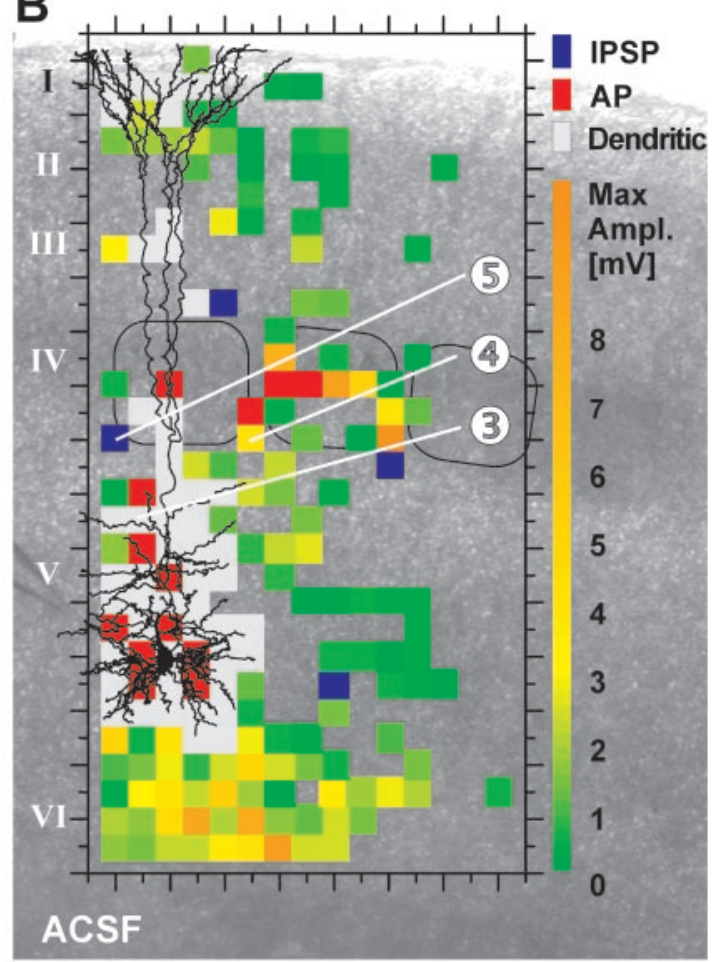

D

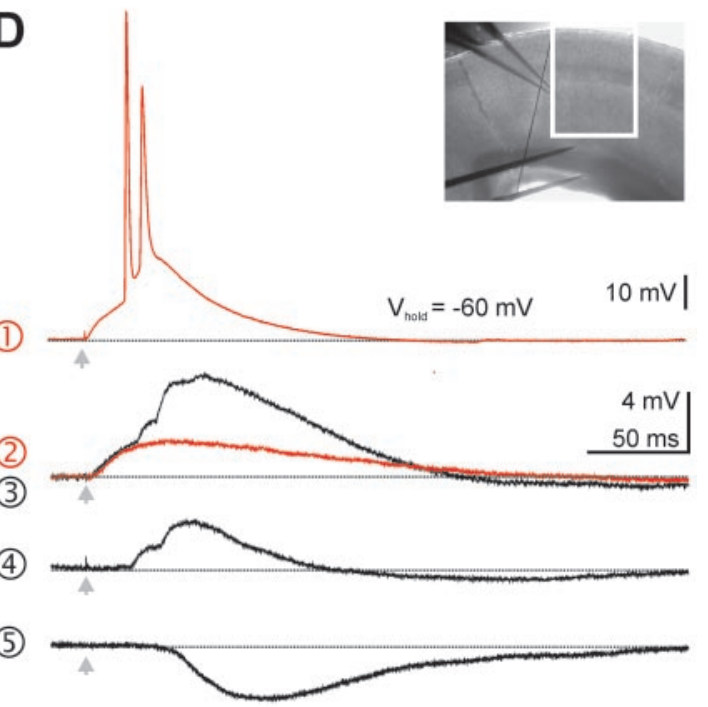

Figure 9. Topographic maps of uncaged glutamate-induced activity during blockade of synaptic transmission $(A)$ and in normal bathing solution $(B)$. $A$, Color-coded map of the amplitudes of depolarizations evoked by direct dendritic activation recorded at resting membrane potential $\left(V_{\mathrm{rmp}}=-69 \mathrm{mV}\right)$ in bathing solution containing $0.2 \mathrm{mM} \mathrm{Ca}^{2+} / 4 \mathrm{mM} \mathrm{Mg}^{2+}$. Fields eliciting an action potential are marked in red. B, Responses recorded in normal ACSF at a depolarized membrane potential $\left(V_{\text {hold }}=-60 \mathrm{mV}\right.$ ) consist of IPSPs (blue), action potentials (red), and EPSPs of variable amplitudes ( green to orange). Fields that elicit a response with a delay of $<8 \mathrm{msec}$ caused by direct dendritic activation are marked in gray even when EPSPs were additionally elicited. This separation was obtained by an analysis of the delay-to-onset times as shown in $C$. Stimulation of distal fields in layer IV elicited APs only at the depolarized holding potential of $-60 \mathrm{mV}$, but not at the resting membrane potential of the cell of $-69 \mathrm{mV}$. $C$, Delay-to-onset times calculated from responses obtained from two IB and two RS cells recorded in low $\mathrm{Ca}^{2+} /$ high $\mathrm{Mg}^{2+}-\mathrm{ACSF}$ as well as in normal ACSF. In low Ca ${ }^{2+} / \mathrm{high}$ $\mathrm{Mg}^{2+}$-ACSF all responses were recorded within the first $8 \mathrm{msec}$. In normal ACSF the delay-to-onset times of the first response are given. Note that the responses with a delay-to-onset $<8 \mathrm{msec}$ are comparable to the responses recorded in low $\mathrm{Ca}^{2+} / \mathrm{high}^{\mathrm{Mg}}{ }^{2+}$-ACSF. The remaining responses had delay-to-onset times $>10 \mathrm{msec}$. $D$, Representative responses recorded in low $\mathrm{Ca}^{2+} /$ high $\mathrm{Mg}^{2+}$-ACSF (red) and normal ACSF (black) to activation of fields as shown in $A$ and $B$. Suprathreshold depolarization was caused by direct perisomatic activation (trace 1 ). Direct dendritic activation causes a transient depolarization (trace 2). Activation of the same site in normal ACSF induces an excitatory input to the IB cell consisting of summed EPSPs (trace 3), in addition to the direct dendritically evoked depolarization. Synaptic excitatory and inhibitory inputs during stimulation of sites in ACSF are shown in traces 4 and 5 . In these and the following maps, the borders of the barrels are outlined in black. 
A
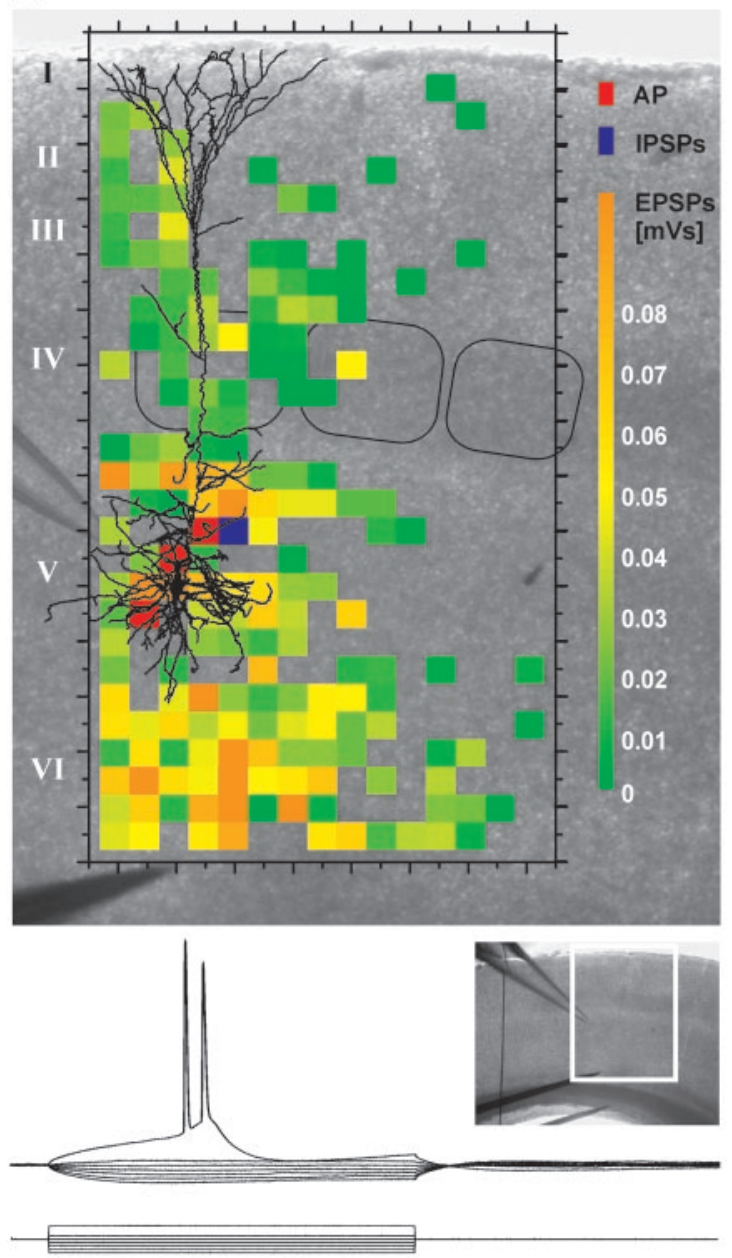

B

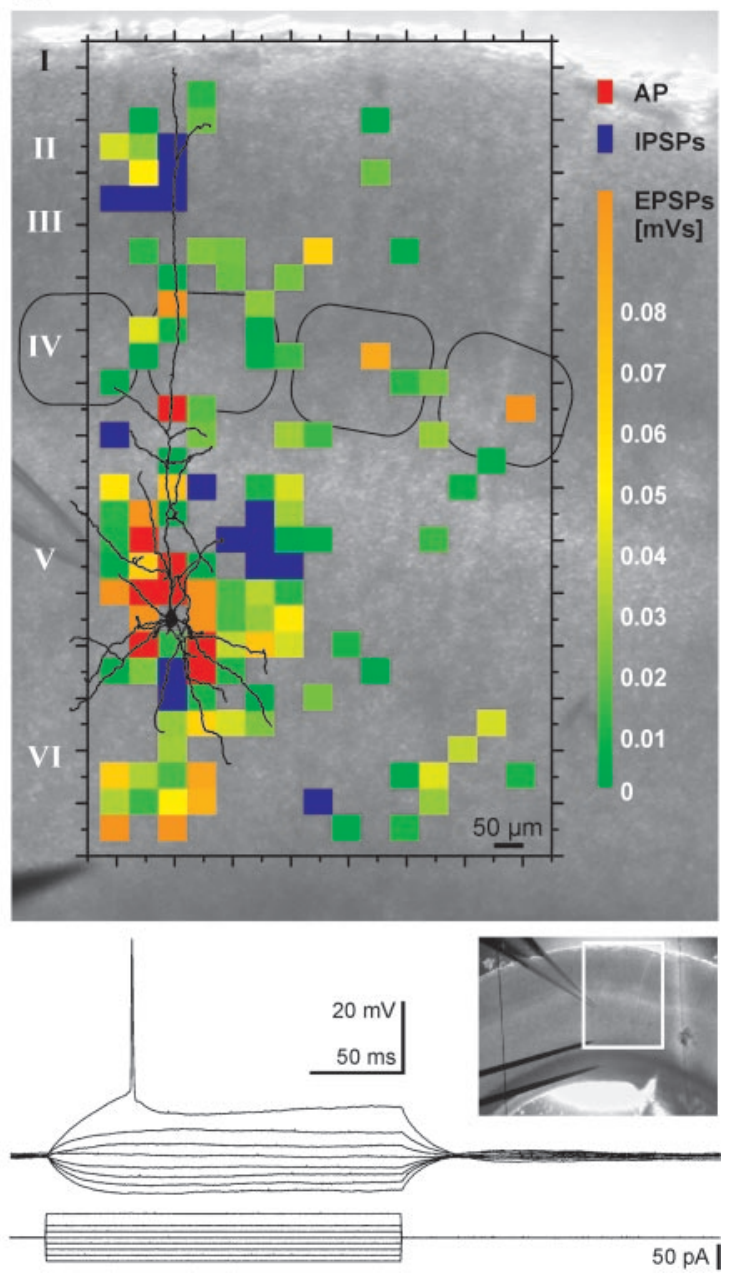

Figure 10. Representative topographic maps of functional connectivity of an IB cell $(A)$ and an RS cell $(B)$ at $V_{\text {hold }}=-60 \mathrm{mV}$. The maps illustrate the integrals of EPSPs recorded within $150 \mathrm{msec}$ after stimulus, fields of origin for inhibitory inputs, and action potentials. Note that the IB cells as well as the RS cells receive excitatory inputs during stimulation of fields in layers II-VI. A photomicrograph indicating the enlarged cortical area within the slice (outlined in white) and the response of the cells to injection of depolarizing and hyperpolarizing current pulses in normal ACSF at $V_{\text {rmp }}$ (IB cell: $-70 \mathrm{mV}$; RS cell: $-67 \mathrm{mV}$ ) are presented below the respective maps.

soma of the cell, thus providing a layer-specific resolution. For that purpose, we performed control recordings from neurons in all cell-containing cortical layers. Furthermore, we defined a criterion to differentiate between synaptic responses resulting from suprathreshold activation of presynaptic neurons and direct nonsynaptic stimulation caused by activation of glutamate receptors on the recorded cell. Recordings from the same cell were performed in normal ACSF as well as in low $\mathrm{Ca}^{2+} /$ high $\mathrm{Mg}^{2+}$. containing solution to block synaptic transmission to allow comparison of the spatial distribution of the different types of evoked activity. The delay-to-onset times were longer for the synaptic responses because of long and variably sized action potential latencies in the presynaptic neurons (Katz and Dalva, 1994; Molnar and Nadler, 1999). Consequently, we can interpret the layer-specific spatial distribution of connected neurons but not the temporal properties of their input. Therefore, the stimulation procedure as well as the data analysis allow us to construct detailed maps of neuronal locations giving rise to intracortical synaptic inputs onto identified layer $\mathrm{V}$ pyramidal cells. In these maps, analysis of percentages of sites with detectable PSPs turned out to be more sensitive to cell type-specific differences than analysis of EPSP integrals. The latter showed a higher variability resulting from a large range of values for each single cell. This variability of synaptic transmission may result partially from paired-pulse facilitation and depression (Thomson, 1997).

\section{Structural properties and firing patterns of layer $\mathbf{V}$ pyramidal cells}

In agreement with previous reports, we found a significant correlation between the morphology of the cell and its intrinsic firing pattern. Layer V cells with a large soma, a thick apical trunk, and a rich apical dendritic tree responded to injection of a suprathreshold current pulse with a burst of action potentials (ChagnacAmitai et al., 1990; Larkman and Mason, 1990) or at least a doublet (Schwindt et al., 1997). In contrast, all regular-spiking cells were characterized by a smaller soma, a thinner apical trunk, and a more restricted dendritic branching pattern. In addition to confirming these properties of different layer $\mathrm{V}$ pyramidal cells, our results demonstrate that these two cell types also differ in their intracortical synaptic inputs. 

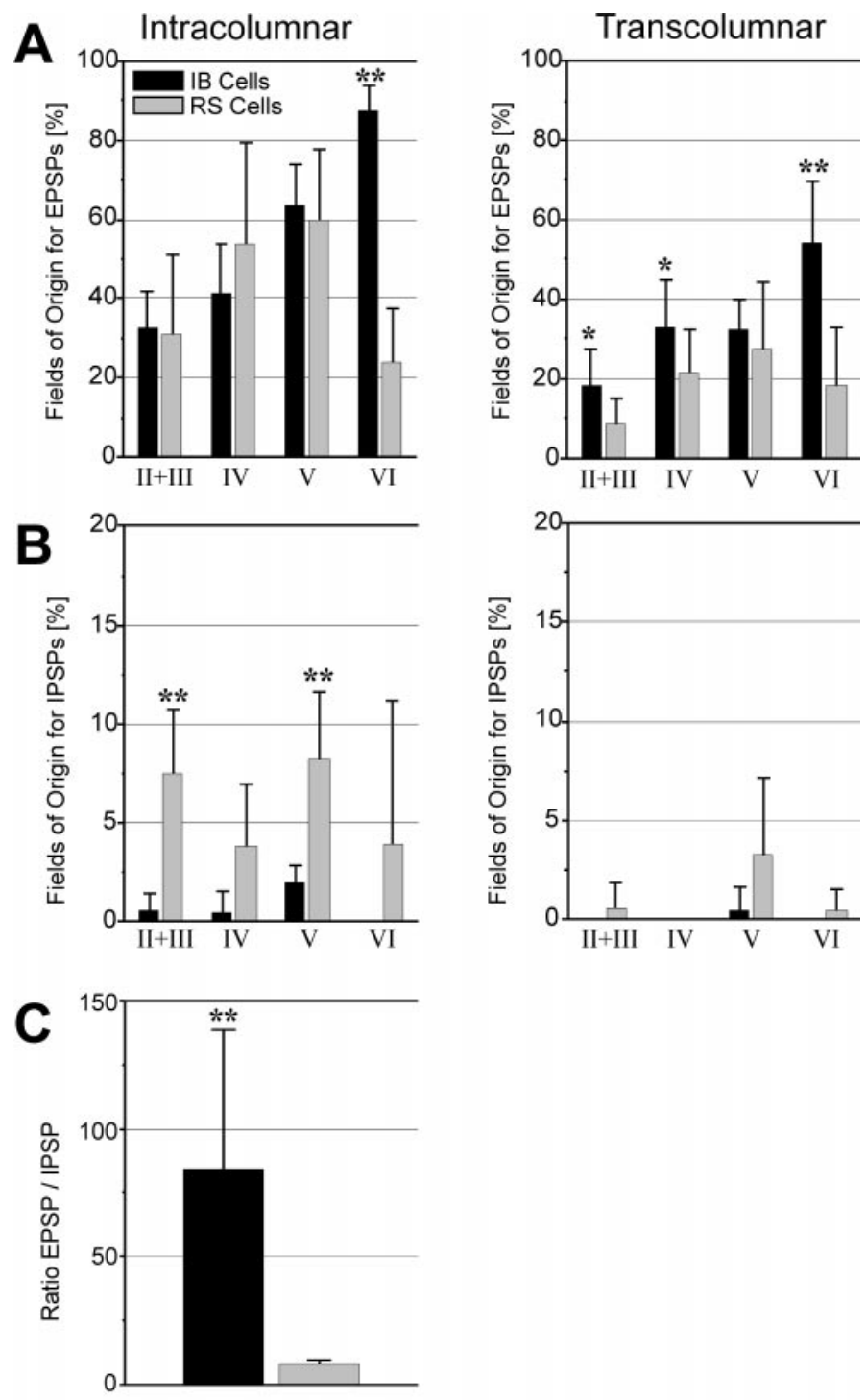

Figure 11. Percentages of presynaptic fields generating excitatory $(A)$ and inhibitory $(B)$ inputs onto layer $\mathrm{V}$ pyramidal cells in relationship to layer- and column-dependent location: IB cells (black columns; $n=7$ ) and RS cells ( gray columns; $n=8$ ). $C$, Ratio of fields generating EPSPs to fields generating IPSPs in IB cells and RS cells. Data are mean \pm SD. Asterisks indicate significant differences at $p<0.05\left({ }^{*}\right)$ and $p<0.01(* *)$ levels.

\section{Intracolumnar and transcolumnar inputs onto layer V pyramidal cells}

The topographic maps show extensive excitatory and inhibitory synaptic inputs from neurons located in layers II-V I onto layer V pyramidal cells. The weak synaptic inhibition of IB neurons, mainly derived from interneurons located relatively close to the recorded cell, as demonstrated here, is in agreement with previous electrophysiological investigations (Chagnac-Amitai and Connors, 1989a; Chagnac-Amitai et al., 1990; Nicoll et al., 1996). The more pronounced inhibitory inputs onto RS cells originated mainly from layers II/III and V of the same column (Nicoll et al., 1996), as well as from layer V of the adjacent column (Salin and Prince, 1996). Inhibitory interneurons in layer IV provided only a weak synaptic input in accordance with their highly restricted axonal arbors (Harris and Woolsey, 1983). These data clearly demonstrate that IB cells are under less inhibitory control than
RS neurons. Therefore IB cells should be capable of distributing their activity reliably within a larger neuronal network.

In our experiments, excitatory inputs from layer II/III, which are supposed to be the main extralaminar source of excitatory input onto layer V pyramidal cells (Thomson and Deuchars, 1997; Reyes and Sakmann, 1999), were comparatively weak and spatially restricted. However, referring to our control experiments (see Materials and Methods), for some cells in layer II/III our stimulation may have been too weak to elicit action potentials. One possible reason for this could be that layer II/III pyramidal cells have lower resting membrane potentials than, for example, layer $\mathrm{V}$ pyramidal cells and require higher depolarization amplitudes to reach threshold (Mason and Larkman, 1990).

We expected excitatory inputs originating from the granular layer to be weak, because (1) anatomical studies have shown relatively sparse layer IV to V projections (Gilbert and Wiesel, 1983; Callaway and Wiser, 1996; Lübke et al., 2000), and (2) because physiological studies have supported a sequential intracortical pathway leading from layer IV to layer II/III and finally to layer V (Armstrong-James et al., 1992; Laaris et al., 2000). In contrast, our results clearly show strong, patchy inputs from layer IV within the same and adjacent column for both cell types. Such strong excitatory influences of layer IV onto layer V were recently described at the population level in a study of functional connectivity in the rat barrel cortex (Staiger et al., 2000). Here we show that in addition to the oligosynaptic pathway mentioned above, a strong monosynaptic input also exists. According to its spatial pattern, this input was probably provided by clusters of strongly coupled spiny neurons in layer IV (Feldmeyer et al., 1999), with most of the synaptic contacts onto layer $\mathrm{V}$ pyramidal cells located in or near the granular layer (Lübke et al., 2000). The possible occurrence of synaptic contacts between axons of spiny stellate neurons and apical dendrites of layer $\mathrm{V}$ pyramidal cells extending through granular and supragranular layers might resolve the discrepancy of an anatomically sparse but functionally potent layer IV to $\mathrm{V}$ input.

The bulk of excitatory synaptic inputs onto IB cells was provided from neurons located in infragranular layers of the same and adjacent column. These dominant excitatory inputs are probably mediated by the extensive intralaminar coupling between layer V IB cells (Chagnac-Amitai et al., 1990) and ascending collaterals arising from layer VI spiny neurons (Zhang and Deschenes, 1997). Photostimulation of fields in layer VI caused strong and widespread excitatory responses in IB cells, whereas RS neurons received only moderate inputs from this layer. This finding indicates a strong but cell type-dependent interaction between the two major cortical output layers V and VI (Deschenes et al., 1998). For RS cells, inputs from layer V were more pronounced than from layer VI, indicating a strong coupling between RS cells and other pyramidal cells within layer V.

\section{Functional implications}

The present study demonstrates cell type-specific differences in functional connectivity for the two major types of excitatory cells in layer $\mathrm{V}$ of the rat barrel cortex. Extensive intracolumnar and transcolumnar excitatory inputs onto IB cells are provided by neurons from all layers and accompanied by only weak inhibitory control. Under physiological conditions, IB cells may effectively integrate inputs from several cortical columns. Ensembles of these cells could possibly function as intracortical pacemakers and mediate widespread synchronous activity with characteristic rhythmic properties (Chagnac-Amitai and Connors, 1989b; Silva 
et al., 1991; Flint and Connors, 1996). Such rhythms are considered to be instrumental in the integration of different features of a distinct sensory percept (Singer, 1993) and have been shown to exist in the barrel cortex as well (Barth and Di, 1991; Jones and Barth, 1997). According to our data, IB cells may not only synchronize cortical circuits, but may also boost cortical outputs to subcortical and feedback circuits (Ahissar et al., 2000). Finally, the strong and widespread intracortical interactions, the weak inhibitory control, and the burst discharge may promote the initiation and propagation of epileptiform discharge. Therefore, layer V IB cells could play a critical role in synchronizing cortical modules under physiological as well as pathophysiological conditions (Connors and Amitai, 1993).

The complex excitatory and inhibitory intracolumnar control of RS cells obviously provides them with different informationprocessing capabilities. By feeding back inputs to the supragranular layers, these cells could participate in filtering sensory information by decoding the physical properties of tactile stimuli derived from the respective "principal" whisker (Simons, 1978, 1995). How these "intracolumnar RS" and "transcolumnar IB" circuits interact remains an important issue for further investigations.

In conclusion, our analyses revealed the following aspects of layer V circuitry organization. (1) The specific pattern of functional connectivity of layer $\mathrm{V}$ pyramidal cells correlates with the morphological and electrophysiological properties of these neurons. (2) Both IB and RS cells receive excitatory synaptic inputs from all cortical layers, in a more or less homogenous fashion from layers V and VI, whereas inputs from layers IV and II/III show a patchy pattern. Inputs from layer VI are significantly stronger for IB than for RS pyramidal cells. (3) IB cells receive only a weak inhibitory input, mainly originating locally from within layer V. In contrast, the more extensive inhibitory inputs onto RS cells originate primarily from layers II/III and V of the same column and from layer $\mathrm{V}$ of the adjacent column.

\section{REFERENCES}

Agmon A, Connors BW (1991) Thalamocortical responses of mouse somatosensory (barrel) cortex in vitro. Neuroscience 41:365-379.

Ahissar E, Sosnik R, Haidarliu S (2000) Transformation from temporal to rate coding in a somatosensory thalamocortical pathway. Nature 406:302-306.

Amitai Y (1994) Membrane potential oscillations underlying firing patterns in neocortical neurons. Neuroscience 63:151-161.

Angulo MC, Staiger JF, Rossier J, Audinat E (1999) Developmental synaptic changes increase the range of integrative capabilities of an identified excitatory neocortical connection. J Neurosci 19:1566-1576.

Armstrong-James M (1975) The functional status and columnar organization of single cells responding to cutaneous stimulation in neonatal rat somatosensory cortex S1. J Physiol (Lond) 246:501-538.

Armstrong-James M, Fox K, Das-Gupta A (1992) Flow of excitation within rat barrel cortex on striking a single vibrissa. J Neurophysiol 68:1345-1358.

Barth DS, Di S (1991) Laminar excitability cycles in neocortex. J Neurophysiol 65:891-898.

Callaway EM, Wiser AK (1996) Contributions of individual layer 2-5 spiny neurons to local circuits in macaque primary visual cortex. Vis Neurosci 13:907-922.

Chagnac-Amitai Y, Connors BW (1989a) Horizontal spread of synchronized activity in neocortex and its control by GABA-mediated inhibition. J Neurophysiol 61:747-758.

Chagnac-Amitai Y, Connors BW (1989b) Synchronized excitation and inhibition driven by intrinsically bursting neurons in neocortex. J Neurophysiol 62:1149-1162.

Chagnac-Amitai Y, Luhmann HJ, Prince DA (1990) Burst generating and regular spiking layer 5 pyramidal neurons of rat neocortex have different morphological features. J Comp Neurol 296:598-613.

Connors BW, Amitai Y (1993) Generation of epileptiform discharge by local circuits of neocortex. In: Epilepsy: models, mechanism and concepts (Schwarzkroin, ed), pp 388-423. Cambridge, MA: Cambridge UP.
Connors BW, Gutnick MJ, Prince DA (1982) Electrophysiological properties of neocortical neurons in vitro. J Neurophysiol 48:1302-1320.

Dantzker JL, Callaway EM (2000) Laminar sources of synaptic input to cortical inhibitory interneurons and pyramidal neurons. Nat Neurosci 3:701-707.

Deschenes M, Veinante P, Zhang ZW (1998) The organization of corticothalamic projections: reciprocity versus parity. Brain Res Rev 28:286-308.

Feldmeyer D, Egger V, Lübke J, Sakmann B (1999) Reliable synaptic connections between pairs of excitatory layer 4 neurones within a single "barrel" of developing rat somatosensory cortex. J Physiol (Lond) 521:169-190.

Flint AC, Connors BW (1996) Two types of network oscillations in neocortex mediated by distinct glutamate receptor subtypes and neuronal populations. J Neurophysiol 75:951-956.

Gilbert CD, Wiesel TN (1983) Clustered intrinsic connections in cat visual cortex. J Neurosci 3:1116-1133.

Harris RM, Woolsey TA (1983) Computer-assisted analyses of barrel neuron axons and their putative synaptic contacts. J Comp Neurol 220:63-79.

Hefti BJ, Smith PH (2000) Anatomy, physiology, and synaptic responses of rat layer $\mathrm{V}$ auditory cortical cells and effects of intracellular GABA(A) blockade. J Neurophysiol 83:2626-2638.

Jones MS, Barth DS (1997) Sensory-evoked high-frequency (gammaband) oscillating potentials in somatosensory cortex of the unanesthetized rat. Brain Res 768:167-176.

Kasper EM, Larkman AU, Lübke J, Blakemore C (1994) Pyramidal neurons in layer 5 of the rat visual cortex. I. Correlation among cell morphology, intrinsic electrophysiological properties, and axon targets. J Comp Neurol 339:459-474.

Katz LC, Dalva MB (1994) Scanning laser photostimulation: a new approach for analyzing brain circuits. J Neurosci Methods 54:205-218.

Kötter R, Staiger JF, Zilles K, Luhmann HJ (1998) Analyzing functional connectivity in brain slices by a combination of infrared video microscopy, flash photolysis of caged compounds and scanning methods. Neuroscience 86:265-277.

Laaris N, Carlson GC, Keller A (2000) Thalamic-evoked synaptic interactions in barrel cortex revealed by optical imaging. $\mathrm{J}$ Neurosci 20:1529-1537.

Larkman A, Mason A (1990) Correlations between morphology and electrophysiology of pyramidal neurons in slices of rat visual cortex. I. Establishment of cell classes. J Neurosci 10:1407-1414.

Lübke J, Egger V, Sakmann B, Feldmeyer D (2000) Columnar organization of dendrites and axons of single and synaptically coupled excitatory spiny neurons in layer 4 of the rat barrel cortex. J Neurosci 20:5300-5311.

Markram H, Lübke J, Frotscher M, Roth A, Sakmann B (1997) Physiology and anatomy of synaptic connections between thick tufted pyramidal neurones in the developing rat neocortex. J Physiol (Lond) 500:409-440.

Mason A, Larkman A (1990) Correlations between morphology and electrophysiology of pyramidal neurons in slices of rat visual cortex. II. Electrophysiology. J Neurosci 10:1415-1428.

Molnar P, Nadler JV (1999) Mossy fiber-granule cell synapses in the normal and epileptic rat dentate gyrus studied with minimal laser photostimulation. J Neurophysiol 82:1883-1894.

Nicoll A, Kim HG, Connors BW (1996) Laminar origins of inhibitory synaptic inputs to pyramidal neurons of the rat neocortex. J Physiol (Lond) 497:109-117.

Paxinos G, Watson C (1986) The rat brain in stereotaxic coordinates. London: Academic.

Reyes A, Sakmann B (1999) Developmental switch in the short-term modification of unitary EPSPs evoked in layer $2 / 3$ and layer 5 pyramidal neurons of rat neocortex. J Neurosci 19:3827-3835.

Salin PA, Prince DA (1996) Electrophysiological mapping of GABAA receptor-mediated inhibition in adult rat somatosensory cortex. J Neurophysiol 75:1589-1600.

Schubert D, Staiger JF, Cho N, Kötter R, Zilles K, Luhmann HJ (2000) Caged glutamate photolysis reveals layer-specific intra- and intercolumnar functional connectivity of layer 5 pyramidal cells in rat barrel cortex. Eur J Neurosci [Suppl] 12:431

Schwindt P, O'Brien JA, Crill W (1997) Quantitative analysis of firing properties of pyramidal neurons from layer 5 of rat sensorimotor cortex. J Neurophysiol 77:2484-2498.

Silva LR, Amitai Y, Connors BW (1991) Intrinsic oscillations of neocortex generated by layer 5 pyramidal neurons. Science 251:432-435.

Simons DJ (1978) Response properties of vibrissa units in rat SI somatosensory neocortex. J Neurophysiol 41:798-820.

Simons DJ (1985) Temporal and spatial integration in the rat SI vibrissa cortex. J Neurophysiol 54:615-635.

Simons DJ (1995) Neuronal integration in the somatosensory whisker/ barrel cortex. In: Cereb cortex. The barrel cortex of rodents (Jones EG, Diamond IT, eds), pp 263-297. New York: Plenum.

Singer W (1993) Synchronization of cortical activity and its putative role in information processing and learning. Annu Rev Physiol 55:349-374. 
Staiger JF, Kötter R, Zilles K, Luhmann HJ (2000) Laminar characteristics of functional connectivity in rat barrel cortex revealed by stimulation with caged-glutamate. Neurosci Res 37:49-58.

Thomson AM (1997) Activity-dependent properties of synaptic transmission at two classes of connections made by rat neocortical pyramidal axons in vitro. J Physiol (Lond) 502:131-147.

Thomson AM, Deuchars J (1994) Temporal and spatial properties of local circuits in neocortex. Trends Neurosci 17:119-126.

Thomson AM, Deuchars J (1997) Synaptic interactions in neocortical local circuits: dual intracellular recordings in vitro. Cereb Cortex 7:510-522.

Thomson AM, Deuchars J, West DC (1993) Large, deep layer pyramidpyramid single axon EPSPs in slices of rat motor cortex display paired pulse and frequency-dependent depression, mediated presynaptically and self-facilitation, mediated postsynaptically. J Neurophysiol 70:2354-2369.

Welker C, Woolsey TA (1974) Structure of layer IV in the somatosen- sory neocortex of the rat: description and comparison with the mouse. J Comp Neurol 158:437-453.

Williams SR, Stuart GJ (1999) Mechanisms and consequences of action potential burst firing in rat neocortical pyramidal neurons. J Physiol (Lond) 521:467-482.

Wise SP, Jones EG (1976) The organization and postnatal development of the commissural projection of the rat somatic sensory cortex. J Comp Neurol 168:313-343.

Woolsey TA, Van der Loos H (1970) The structural organization of layer IV in the somatosensory region (SI) of mouse cerebral cortex. The description of a cortical field composed of discrete cytoarchitectonic units. Brain Res 17:205-242.

Zhang ZW, Deschenes M (1997) Intracortical axonal projections of lamina V I cells of the primary somatosensory cortex in the rat: a single-cell labeling study. J Neurosci 17:6365-6379.

Zhu JJ, Connors BW (1999) Intrinsic firing patterns and whisker-evoked synaptic responses of neurons in the rat barrel cortex. J Neurophysiol 81:1171-1183. 